ROSEANE ARCANJO PINHEIRO

\title{
GÊNESE DA IMPRENSA NO MARANHÃO NOS SÉCULOS XIX E XX
}

Universidade Metodista de São Paulo Programa de Pós-Graduação em Comunicação Social São Bernardo do Campo, 2007 


\section{GÊNESE DA IMPRENSA NO MARANHÃO NOS SÉCULOS XIX E XX}

Dissertação apresentada em cumprimento parcial às exigências do Programa de Pós-Graduação em Comunicação Social, da UMESP - Universidade Metodista de São Paulo, para obtenção do grau de Mestre.

Orientador: Prof. Dr. José Marques de Melo:

Universidade Metodista de São Paulo

Programa de Pós-Graduação em Comunicação Social

São Bernardo do Campo, 2007 


\section{FOLHA DE APROVAÇÃO}

A dissertação Gênese da Imprensa no Maranhão nos Séculos XX e XXI, elaborada por Roseane Arcanjo Pinheiro foi defendida no dia. de. ..de 2007 , tendo sido:

( ) Reprovada

( ) Aprovada, mas deve incorporar nos exemplares definitivos modificações sugeridas pela banca examinadora, até 60 (sessenta) dias a contar a data da defesa.

( ) Aprovada

( ) Aprovada com louvor

Banca Examinadora:

Área de concentração: Processos Comunicacionais

Linha de Pesquisa:

Projeto Temático: 
Aos meus pais:

Basílio e Ivonete, por acreditarem nos meus sonhos. 
“A imprensa é a vista da Nação. Por ela é que a Nação acompanha o que lhe passa ao perto e ao longe, enxerga o que lhe malfazem, devassa o que lhe ocultam e tramam, colhe o que lhe sonegam, ou roubam, percebe onde lhe alvejam, ou nodoam, mede o que cerceiam, ou destroem, vela pelo que lhe interessa, e se acautela do que a ameaça”.

Rui Barbosa, na obra "A Imprensa e o Dever da Verdade", editada pela primeira vez em 1920. 


\section{Agradecimentos,}

A Deus, fonte de vida e amor;

À minha família, pais, irmãs, irmão e sobrinhos - Ivonete, Basílio, Rei, Rose Elci, Cléa, Nelbe, Wellington, Polliane e Heitor, pelo carinho e as vibrações positivas, mesmo eu estando longe da nossa terra, a querida Manaus;

Ao orientador, Prof. Dr. José Marques de Melo, pelo confiança, pela acolhida em São Paulo, e pelo seu exemplo de amor ao jornalismo e ao magistério;

Aos professores da Universidade Metodista de São Paulo, por tornarem esse projeto tão produtivo e feliz;

À amiga e "irmã do coração", Edvânia Kátia por ter abraçado a paixão pela história da imprensa maranhense e estado à frente da organização do maior encontro sobre a temática no Maranhão, o IV Encontro Nacional da História da Mídia, que ocorreu no período de 30 de maio a 2 de junho de 2006, em São Luís-MA;

Ao carinho dos amigos e colegas do Mestrado: Bruna, Sandra, Lennine, Ingrid, Marcelle, Nayara, Backer, Sirlei, Aline, entre tantos outros, por marcarem com alegria e companheirismo a minha passagem pela pós-graduação e por São Paulo;

Aos jornalistas companheiros (as) da Associação Maranhense de Imprensa - Mirlene Bezerra, Wal Oliveira, Paulo Washington, Rosenira Alves, entre outros - por compartilharmos os mesmos sonhos e lutarmos bravamente pelo jornalismo ético, socialmente responsável e de qualidade;

Ao prof. Dr. Sofiane Labidi, que inaugurou com destemor e humildade uma nova página da história da pesquisa e da ciência no Estado do Maranhão.

Aos companheiros da Rede Alfredo de Carvalho, fonte de inspiração de novos desafios no desbravar da história da imprensa e da mídia brasileira;

Aos colegas historiadores do Maranhão, Marcelo Cheche, Wagner Cabral e Kelcilene Rose, pelo incentivo e troca de idéias.

Ao Prof. Dr. Jorge Pedro, da Universidade Fernando Pessoa/Porto, que d'além mar me ajudou com referências sobre a história de Portugal.

Ao fotógrafo Nael Reis, que registrou as capas dos jornais mais antigos do Maranhão, que estão em anexo.

Ao prof. Dr. Walmir de Albuquerque Barbosa pelo exemplo, garra e ousadia, ao orientar 12 bolsistas do Programa Especial de Treinamento-PET/Capes/MEC, entre 1993 e 1996 na Universidade Federal do Amazonas, e plantar no meu coração o desejo de ser pesquisadora da imprensa brasileira.

A todos que direta ou indiretamente colaboraram para a realização deste acalentado projeto. 


\section{LISTA DE TABELAS}

QUADRO 1 - Cronologia da chegada da imprensa aos estados do território 24

QUADRO 2 - Divisões administrativas do Maranhão 29

QUADRO 3 - Ocupação do território do Maranhão 34

QUADRO 4 - Habitantes do Maranhão em 1821

QUADRO 5 - Municípios maranhenses e seus jornais pioneiros entre 1821-2006

QUADRO 6 - Cidades com primeiros jornais

entre 1821-2006

QUADRO 7 - Os primeiros jornais registrados

na Região Norte

QUADRO 8 - Jornais por município - Região Norte 1821 a 2006

QUADRO 9 - Perfis predominantes na capital

-1821 a 2006

QUADRO 10 - Periodicidade dos jornais na capital

-1821 a 2006

QUADRO 11 - Perfil dos jornais da Região

Norte 1821-2006

QUADRO 12 - Periodicidade dos jornais na

Região Norte - 1821 a 2006

QUADRO 13 - Municípios da Região Norte

sem registro de jornais

QUADRO 14 - Municípios da Região Norte com registro de jornais

QUADRO 15 - Primeiros jornais registrados na

Região Leste 1821-2006

QUADRO 16 - Quadro com totalidade de jornais

da Região Leste 1821-2006

QUADRO 17 - Perfis predominantes dos jornais na

Região Leste - 1821 a 2006 
QUADRO 18 - Periodicidade dos jornais na

Região Leste - 1821 a 2006

QUADRO 19 - Cidades com registro de jornais

no Leste

QUADRO 20 - Cidades sem registro de

jornais no Leste

QUADRO 21 - Os primeiros registros de jornais

no Sul - 1821 e 2006

QUADRO 22 - Totalidade de jornais por município

Região Sul 1821-2006

QUADRO 23 - Perfis predominantes dos jornais

na Região Sul 1821 a 2006

QUADRO 24 - Periodicidade dos jornais na

Região Sul - 1821 a 2006

QUADRO 25 - Município do Sul com jornais

1821-2006

QUADRO 26 - Municípios do Sul sem jornais

1821-2006

QUADRO 27 - Jornais da Região Central

- 1821-2006

QUADRO 28 - Totalidade de jornais por

município Região Central 1821-2006

QUADRO 29 - Perfis predominantes dos jornais na Região Central-1821 a 2006

QUADRO 30 - Periodicidade dos jornais

na Região Central - 1821 a 2006

QUADRO 31 - Municípios com registros

de jornais - Centro

QUADRO 32- Municíp ios sem registros

de jornais - Centro

QUADRO 33 - Os primeiros registros de jornais da Região Oeste 1821- 2006

QUADRO 34 - Totalidade de jornais por 
município Região Oeste 1821-2006

QUADRO 35 - Perfis predominantes dos jornais na Região Oeste-1821 a 2006

QUADRO 36 - Periodicidade dos jornais na Região Oeste - 1821 a 2006

QUADRO 37 - Municípios com registro de jornais na Região Oeste

QUADRO 38 - Municípios sem registros de jornais na Região Oeste

QUADRO 39 - As regiões maranhenses e

as causas socioculturais

QUADRO 40 - Registro de Identificação do

Jornal $O$ Conciliador

101

QUADRO 41 - Presença de anúncios

102

QUADRO 42 - Primeira Página

107

QUADRO 43 - Categorias da Matéria

107

QUADRO 44 - Redatores do jornal

109

QUADRO 45 - Principais Fontes

110

QUADRO 46 - Gêneros Jornalísticos

111

QUADRO 47 - Gênero Informativo

QUADRO 48 - Gênero Opinativo

QUADRO 49 - Ilustrações

QUADRO 50 - Procedência das Notícias

QUADRO 51 - Vinculação Geográfica

QUADRO 52 - Posicionamento sobre a

independência do Brasil

SUMÁRIO

INTRODUÇÃO

CAPÍTULO I- A IMPLANTAÇÃO DA IMPRENSA NO BRASIL E NO MARANHÃ̃O

1. A chegada tardia da imprensa aos territórios portugueses na América 
2. A chegada tardia na imprensa ao Maranhão: causas socioculturais responsáveis pelo retardamento

1. A trilha dos primeiros jornais maranhenses

2. Região Norte

3. Região Leste

66

4. Região Sul

72

5. Região Central

6. Região Oeste

7. A evolução da imprensa no interior

e os fatores socioculturais

CAPÍTULO III - O JORNALISMO EM SÃO LUIS:

88

\section{NAS LINHAS DE O CONCILIADOR}

1. Dos impressos manuscritos ao nascimento da Tipografia Maranhense

2. No rastilho da Revolução do Porto

e da liberdade de imprensa

3. O jornal O Conciliador do Maranhão na ebulição da independência

4. Entre liberais e conservadores: perfil de

5. Do primeiro editorial à última reportagem

Título: Gênese da Imprensa no Maranhão nos Séculos XIX e XX 


\section{Resumo}

A imprensa brasileira nasceu tardiamente, 276 anos após o início da ocupação da colônia americana pela Coroa portuguesa. Investigando as singularidades desse processo na região Nordeste, pretende-se resgatar a gênese das atividades tipográficas no Maranhão, cujo marco é o jornal $O$ Conciliador do Maranhão, que circulou entre novembro de 1821 e julho de 1823 . O objetivo é identificar os fatores socioculturais que explicam o retardamento da imprensa no Estado. Para tanto, foi realizada uma pesquisa histórica adotando dupla estratégia metodológica: a) qualitativa: destinada a compreender as circunstâncias que contribuíram para delongar a chegada da imprensa à capital maranhense, condicionando a natureza da produção jornalística nascente; b) quantitativa: visando reconstituir o perfil jornalístico, a política editorial e a estrutura morfológica do jornal pioneiro, através da análise do conteúdo manifesto de uma amostra daquele periódico.

Palavras-chave: Identidade Midiática Brasileira; História da Imprensa; Maranhão; Jornal O Conciliador do Maranhão; Séculos XIX e XX.

Titulo : Génesis de la imprenta en el Maranhão en los siglos XIX e XX. 


\section{Resumo}

La imprenta brasileña nació tardón, 276 años apues el começo de la ocupación de la colonia americana por la corona portuguesa. Investigando lãs singularidades de eso proceso en la región Nordeste, pretendese resgatar la génesis de lãs actividades tipográficas del Maranhão, cuyo marco ès el periódico El Conciliador do Maranhon que circulou entre Noviembre de 1821 y Julio de 1823. Lo objetivo ès identificar los fatores socioculturales que explican el retardamiento de la imprenta en el Estado. Para tanto, fue realisada una pesquisa historica adaptando dupla estrategia metodologica: a) qualitativa: destinada a comprender lãs circunstancias que contribuiran para retarda la llegada de la imprenta a la capital maranhense, condicionando la naturaleza de la

produción periodística naciente; b) quantitativa: visando reconstituir el perfil periodistico, la politica editorial y la estructura morfologica del periodico pionero, através de la analises del contenido manifiesto de una amuestra de aquel periódico.

Palabras-llave: Identidad Midiatica Brasileña; Historia de la Imprenta; Maranhão; periódico O Conciliador do Maranhão; Siglos XIX e XX.

Title: Genesis of Press in Maranhão in the centuries XIX and XX. 


\begin{abstract}
The Brazilian press was late born, 276 years after the start of the American colony occupation by the Portuguese Crown. Investigating the particularities of this process in the Northeast region, there is an intention to rescue the genesis of typographic activities in Maranhão, which milestone is the newspapers $O$ Conciliador do Maranhão that was issued between November 1821 and July 1823. The objective of this is to identify the sociocultural factors that explain the delay of the press in the State. To do so, it was performed a historical research adopting double methodological strategy: a) qualitative: in order to comprehend the circumstances that contributed to delay the arrival of press to the maranhense capital, conditioning the nature of arising journalistic production; b) quantitative: aiming to reconstruct the journalistic profile, the editorial politic and the morphologic structure of the pioneer newspaper, through content analysis of a sample from that periodic.
\end{abstract}

Key - words: Brazilian Media Identity; Press History; Maranhão; newspapers $O$ Conciliador do Maranhão; Centuries XIX and XX.

\title{
INTRODUÇÃO
}

Focalizamos neste trabalho o nascimento da imprensa e do jornalismo no Maranhão, à luz das causas socioculturais, ou seja, de um conjunto de acontecimentos políticos, intelectuais, 
econômicos, culturais e sociais, que articulados e interdependentes, explicam a chegada tardia da imprensa aos territórios portugueses na América. Durante a investigação foi adotada dupla estratégia metodológica: a) qualitativa: destinada a compreender as circunstâncias que contribuíram para delongar a chegada da imprensa à capital maranhense e b) quantitativa, que ocorreu em duas etapas: ao descortinarmos a evolução da imprensa local, utilizando o critério da divisão em regiões (norte, sul, leste, oeste e centro) e ao realizarmos a análise de conteúdo do jornal $O$ Conciliador.

Adotamos o método histórico para compreender o aparecimento da imprensa no Maranhão e o papel que assumiu no desenvolvimento social e político do Estado, porque entendemos que as atividades tipográficas nasceram sob determinadas condições socioculturais, atendendo às demandas da sociedade. De acordo com Lakatos \& Marconi (1991, p.82):

O método histórico consiste em investigar acontecimentos, processos e instituições do passado para verificar sua influência na sociedade de hoje, pois as instituições alcançaram sua forma atual através de alterações de suas partes componentes, ao longo do tempo, influenciadas pelo contexto cultural particular de cada época. Seu estudo, para uma melhor compreensão do papel que desempenham na sociedade, deve remontar aos períodos de sua formação e modificações.

Na primeira fase da investigação, realizamos a leitura inicial das causas socioculturais que retardaram a chegada da letra impressa ao Maranhão. Para apreendermos esse fenômeno elencamos os seguintes fatores:

a) Ocupação lenta do território - As primeiras tentativas de ocupação da capitania do Maranhão ocorreram 112 anos após a chegada dos portugueses à colônia. Esse quadro foi resultado das invasões de franceses e holandeses, atraídos pelas riquezas do território;

b) Atraso econômico - Até meados do século XVIII, o Maranhão sobrevivia das exportações de produtos Apenas na metade do século XVIII, ocorreu um crescimento econômico;

c) Exclusão social - a população era formada predominantemente pelas camadas mais pobres.

No decorrer do trabalho e aprofundando as leituras, ampliamos o leque de causas socioculturais, que dividimos em grandes blocos - as causas políticas, econômicas, sociais e 
culturais, sobre as quais discorremos no Capítulo I. Aplicamos nessa etapa, as técnicas de pesquisa bibliográfica e documental.

A evolução da imprensa maranhense no século XIX foi abordada no Capítulo II, tendo como referenciais teóricos principais os autores maranhenses das áreas da Comunicação, da História e da Geografia: Lopes (1959), Silva (1981), Jorge (1987), Serra (2001), Frias (2001). Coelho Netto (1979), Paxeco (1998), Coutinho (1994), Meirelles (2001), Nascimento (2001), Cabral (1992) e Viveiros (1954), entre outros. O mapeamento feito sobre o surgimento dos jornais no território maranhense foi construído a partir dos catálogos da Biblioteca Benedito Leite, onde está o maior acervo de periódicos do Estado e da articulação desses números com as informações das obras citadas.

Quanto ao terceiro e último capítulo, a respeito dos primeiros passos do jornalismo em São Luís através de $O$ Conciliador, fizemos uma análise de conteúdo manifesto, a partir da aplicação de protocolo de pesquisa, tabulação e interpretação dos dados. O protocolo, que está em anexo, reuniu questões sobre gêneros jornalísticos, número de páginas, seções, cadernos, leitores, suplementos, temáticas, fontes, posicionamento editorial, recursos gráficos, aspectos morfológicos, recursos visuais e redatores.

No ponto vista de Bardin (1977, p.38), a intenção da análise de conteúdo é "a inferência de conhecimentos relativos à condição de produção (ou eventualmente, de recepção), inferência esta que recorre a indicadores (quantitativos ou não)". Adotamos a técnica de análise categorial, na qual fizemos o agrupamento das unidades de registros e depois as realinhamos em grandes temas relativos à circulação do jornal.

O principal marco teórico desse capítulo foi a análise dos gêneros jornalísticos (MARQUES DE MELO, 1986, p.31). A relevância da classificação dos gêneros jornalísticos reside na descrição das singularidades da mensagem, sua forma, conteúdo e temática, permitindo ainda uma visão ampliada das questões políticas, sociais e econômicas que perpassam todos os produtos jornalísticos.

Conforme Marques de Melo (1986, p. 48), os gêneros são classificados em informativos (nota, notícia, reportagem e entrevista), que se estruturam a partir de fatores externos à instituição jornalística e estão relacionados à eclosão e evolução dos acontecimentos. Por sua vez, nos gêneros opinativos (editorial, comentário, artigo e resenha) a mensagem está interligada às variáveis controladas pela instituição jornalística e apresenta duas feições, autoria e a perspectiva que dá sentido à opinião. Tendo como ponto de partida a classificação proposta pelo pesquisador, 
distinguiremos, de forma sucinta, a seguir, as principais mensagens jornalísticas, de acordo com sua estrutura:

\section{Jornalismo Informativo}

a) Nota: relato de acontecimento em processo de configuração;

b) Notícia: relato de um fato que já eclodiu;

c) Reportagem: relato ampliado de um acontecimento que já ocorrido;

d) Entrevista: relato que privilegia um ou mais protagonista do fato.

\section{Jornalismo Opinativo}

a) Editorial: espaço da opinião institucional, sem autoria, mas com angulagem temporal específica, marcada pelo imediatismo e continuidade;

b) Comentário: relato com angulagem temporal específica, caracterizada pelo imediatismo e continuidade, tem autoria explícita;

c) Artigo: relato de autoria definida e que pode aborda fenômenos diferenciados, no entanto não apresenta as características do imediatismo e da continuidade, podendo aparecer aleatoriamente;

d) Resenha: relato com autoria informada e que descobre os valores de bens culturais, mas não tem freqüência estabelecida.

À proposta dos gêneros, agregamos o estudo da morfologia do periódico, de acordo com Kayser (1964, p. 42), determinando o registro de identificação e os elementos da sua estrutura, tais como espaço publicitário, material jornalístico, ilustrações e títulos.

Adotamos a amostragem não-probabilística de semanas compostas e selecionamos 23 edições do jornal, visando cobrir toda o período de circulação do mesmo, de abril de 1821 a julho de 1823, com exceção de junho e outubro de 1821, sobre o qual não há exemplares disponíveis para a consulta no acervo da Biblioteca Pública Estadual. Das 210 edições originais, há 181 que podem ser consultadas pelo público, deste total $12 \%$ foram analisadas pela pesquisa, contabilizando 112 matérias jornalísticas. O jornal O Conciliador, em função de ser obra rara, não pode ser manuseado, mas seus exemplares podem ser lidos em microfilmes e na versão digitalizada. Segue abaixo detalhamento da amostra escolhida:

\begin{tabular}{|l|}
\multicolumn{1}{|c|}{ Jornal O Conciliador do Maranhão } \\
\hline Período de circulação: abril de 1821 a julho de 1823 \\
\hline Universo: 181 exemplares \\
Amostra: 23 exemplares $(12,7 \%)$ \\
\hline Periodicidade: bissemanal (duas vezes por semana) \\
\hline I821 \\
ABR - 1aa semana (1o exemplar da semana) \\
\hline
\end{tabular}




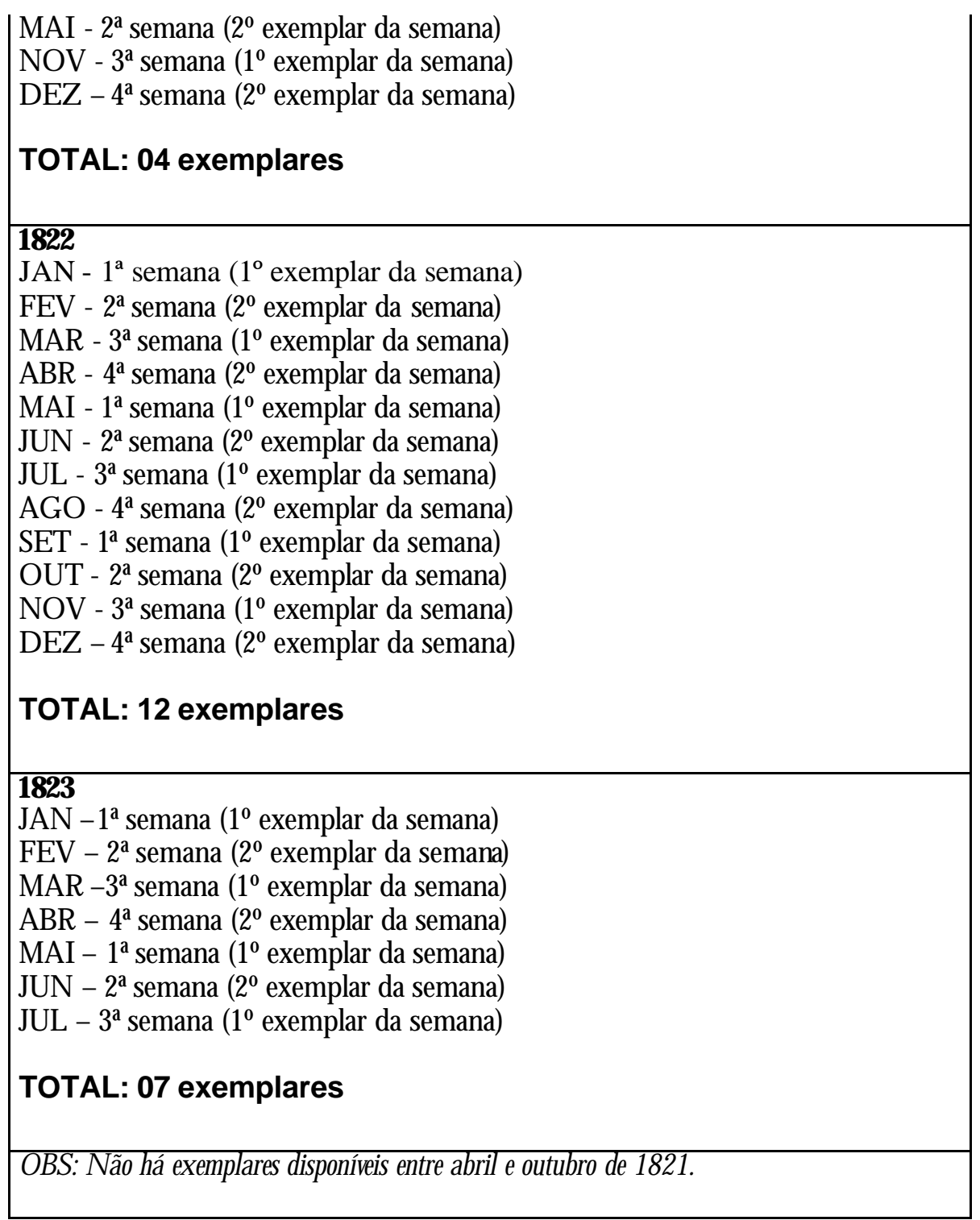

Compreendemos que desencadear pesquisas sobre a história da imprensa no Brasil e suas conexões com os panoramas político, cultural e econômico, tendo em vista o Bicentenário da Imprensa Brasileira, em 2008, é favorecer a compreensão do fazer jornalístico e sua complexa relação com a sociedade. A partir deste olhar, nosso trabalho pode gerar novas reflexões sobre a imprensa local e sua origem, especialmente na Região Nordeste.

Objetivamos ainda trazer mais discussões nos cursos de Jornalismo sobre a imprensa maranhense, que completará 186 anos de fundação em 2007. Atualmente, no Estado, quatro instituições de ensino superior oferecem cursos da área de Comunicação Social, sendo uma universidade pública e três instituições particulares. O projeto poderá incentivar estudos sobre a constituição do jornalismo em São Luís nos séculos XX e XXI e, dessa forma, promoverá a 
sistematização do conhecimento sobre a trajetória dos veículos de comunicação e suas interfaces com o desenvolvimento da cidade e do Estado.

A pesquisa representa uma contribuição para o processo de resgate da história da mídia brasileira, iniciado pela Rede Alfredo de Carvalho-Rede Alcar em 2001, tendo a coordenação do Prof. Dr. José Marques de Melo. A rede é um movimento nacional, em funcionamento através de núcleos estaduais, que objetiva a preservação da trajetória dos meios de comunicação brasileiros e tem a participação de professores, profissionais, estudantes e pesquisadores de instituições públicas e privadas de todo o país.

\section{CAPÍTULO 1}




\section{NO BRASIL E NO MARANHÃO}

\section{Capítulo I \\ IMPLANTAÇÃO DA IMPRENSA NO \\ BRASIL E NO MARANHÃO}

\section{A chegada tardia da imprensa aos territórios portugueses na América}

\subsection{A imprensa no Brasil: verso e reverso}

A vinda da imprensa teve marcos diferentes nas Américas Espanhola e Portuguesa. Nos domínios espanhóis, os serviços tipográficos nasceram em 1533, no México, no princípio do século XVI, durante o processo de ocupação e exploração das riquezas dos novos territórios (MARQUES DE MELO, 2003, p.71). A celeridade da imprensa nas terras hispanoamericanas dependeu das particularidades sócio-econômicas e culturais de cada localidade. O ciclo da 
implantação dos jornais, por exemplo, somente começaria em 1715 (Peru), completando-se em 1845 (Paraguai). (MARQUES DE MELO, 2003, p.84).

Nas possessões portuguesas, atacadas permanentemente por corsários estrangeiros, as atividades jornalísticas sofreram uma demora extraordinária, se comparada aos territórios hispânicos. Com vistas a proteger seus interesses, a Coroa redefiniu a estrutura de seus potentados na América e os dividiu, no século XVI, em Estado do Maranhão, que compreendia o Maranhão, Grão-Pará e Ceará, e Brasil, formado pelos demais territórios, segundo Moraes (1998, p.203).

No Brasil, somente em junho de 1808, circularia o mensário Correio Brasiliense (impresso em Londres) e três meses depois o jornal oficioso Gazeta do Rio de Janeiro (produzido na oficina da Impressão Régia). Enquanto o processo de expansão da imprensa na América Espanhola se deu entre 1715 e 1845, os primeiros jornais brasileiros, oficiais ou não, somente apareceram nas principais cidades das províncias a partir de 1821 (Pernambuco), completando-se o ciclo em 1852 (Amazonas) (MARQUES DE MELO, 2003, p.94-95).

O território lusobrasileiro conheceu a tipografia noventa e três anos depois da América hispano-americana. Esse retardamento e o começo titubeante da imprensa brasileira mereceram explicações de pesquisadores que teceram quadros explicativos sobre os fatores responsáveis pela vinda tardia do jornalismo brasileiro e analisaram suas feições iniciais. As teses, escolhidas por tratarem das principais referências sobre o assunto, sedimentam-se em dois eixos: pontos de vistas sustentados por análises políticas e econômicas sobre o atraso na vinda da letra impressa ao Brasil. Estão sintetizados, respectivamente, nas propostas de Sodré (1999) e Bahia (1972). O segundo grupo reúne perspectivas multifacetadas, calcadas nas condições socioculturais, explicitadas por Marques de Melo (2003), e nas articulações entre processo histórico e conteúdo jornalístico, comentados por Lustosa (2000) e Morel \& Barros (2003). As teses foram agrupadas em razão das similaridades, pois seus autores defendem pontos de vistas semelhantes e suas propostas podem ser complementares.

No terreno das explicações econômicas, se o Brasil demorou a explorar as atividades tipográficas, a razão principal, diagnostica Nelson Werneck Sodré, encontra-se principalmente na ausência de capitalismo e, por fim, na inexistência da classe burguesa nas terras do Reino Português (SODRÉ, 1999, p.28). As proposições, tais como os impedimentos oficiais contrários à ação de tipografias e circulação de livros, as condições econômicas precárias na colônia e o escravismo, embora relevantes, seriam questões secundárias no entendimento do pesquisador, que centrou sua análise no desenvolvimento do capitalismo na colônia. 
Sodré (1999, p. 14) afirma que a transferência da Corte joanina, em 1808, os acontecimentos políticos na Europa e na colônia favoreceram o aparecimento da imprensa de forma rudimentar, um verdadeiro arremedo, um jornalismo trôpego, sustentado pela Metrópole com a finalidade de defender seus interesses e conquistar um público assediado por Hipólito da Costa através do jornal Correio Brasiliense, publicado em Londres entre 1808 e 1822. Em contraponto ao periódico de Hipólito da Costa, o governo português subvencionou a Gazeta do Rio de Janeiro, publicação editada no Brasil, entre 1808 e 1821.

Para o autor, os principais entraves à formação de uma classe dirigente genuinamente brasileira, como as condições materiais e políticas, foram sendo superadas à medida que os fatos sucederam-se desde a chegada da Corte ao Rio de Janeiro, em 1808: a abertura dos Portos, a Revolução Liberal, o retorno da família real a Lisboa e o fim da censura à imprensa (SODRÉ, 1999, p. 35). As tipografias espalhavam-se pela colônia e províncias como a Bahia, Pernambuco, Maranhão, Pará, Minas Gerais e outras localidades, que foram conhecendo seus primeiros jornais graças ao fôlego econômico e o fim da censura prévia, acontecimento conclamado pelas Cortes de Lisboa em 1821.

Para o historiador, as condições políticas necessárias para o engendramento de uma classe dominante, precedido pelo debate de idéias e o fortalecimento da opinião pública, vieram durante o processo de independência do Brasil (SODRÉ,1999, p.43). O desmonte do colonialismo, o complexo jogo de forças entre liberais e absolutistas na Europa e a evolução do quadro político no Brasil foram aos poucos o transformando em um lugar de novas possibilidades. Com a separação entre a colônia e a Coroa, esse território dominado, economicamente parco, politicamente isolado e sem francas lideranças locais, viu o arremedo de imprensa ganhar outros contornos, com um jornalismo estável e a multiplicação de gazetas em toda a colônia.

$\mathrm{O}$ aparecimento tardio dos periódicos brasileiros esteve assentado principalmente na questão política - a formação da classe burguesa - estando as demais questões em segundo plano, como aponta o pesquisador. A vinda da imprensa para as terras espanholas, noventa e três anos antes da implantação das primeiras tipografias brasileiras, teria uma razão fundamental: as possessões espanholas seriam capitalistas e o território brasileiro não o era (SODRÉ, 1999, p.28).

No entanto, como questionou Marques de Melo (2003, p. 109-110), a premissa de Sodré mostroutse limitada, já que todos os territórios coloniais - inglês, português e espanhol apresentavam idênticas relações capitalistas de produção, sustentando empreendimentos agroindustriais ou extrativistas, verdadeiras engrenagens do mapa econômico mundial dos séculos XVIII e XIX. Os postulados do historiador não são rejeitados como um todo, no entanto, 
sua tese perde força quando supervaloriza um único fator - a formação da burguesia capitalista para explicar um fenômeno multifacetado. Na realidade, a implantação da imprensa e suas raízes deram-se em um quadro complexo, com cenários sócio-econômicos distintos no continente norteamericano, coordenados pela matriz mercantilista.

Na mesma linha dos pressupostos econômicos ou políticos, Bahia (1972, p.13) opõe a colônia, sedenta pela liberdade de expressão, versus a Metrópole portuguesa, no papel de asfixiadora de toda tentativa de liberar livros e tipografias. Na ótica do autor, a censura das autoridades foi o principal responsável pelo retardamento das primeiras tipografias em solo brasileiro. O autor não cogita outra explicação senão o obscurantismo de Portugal e sublinha que as tentativas de montagem de prelos e tipografias foram sempre freadas pela legislação da época.

Bahia (1972, p.13) argumenta que o primeiro ato de censura ocorreu em 1706, em Pernambuco, quando um prelo foi apreendido, demonstrando o espírito de clausura quanto à circulação de idéias e informações. Um segundo episódio ocorreu em 1711, quando a publicação Cultura e Opulência do Brasil, de João Antônio Andreoni, foi apreendida, embora liberada pelo Santo Ofício. O governo português recolheu a edição porque entendeu que o livro atiçaria a ambição de outros países sobre as riquezas da colônia. Novamente, em 1747, outro impedimento, desta vez no Rio de Janeiro, onde a Carta Régia de 06 de julho suspendeu a instalação da tipografia de Antônio Isidoro da Fonseca. Esses exemplos sustentariam a versão do pesquisador, bem como as punições previstas aos infratores, que sofriam pena de prisão e exílio para o Reino, enquanto os tipos eram remetidos a Portugal.

No entanto, vê-se que a proposição de Bahia tem frágil sustentação, visto que os casos citados não denotam uma legislação vigorosa e permanente para coibir a chegada das letras impressas. Os fatos citados aconteceram com grandes intervalos, sem estar amarrados a determinações legais rígidas, como aponta Marques de Melo (2003, p.98) ao analisar a questão: "Diríamos que não existiu uma legislação expressamente restritiva à instalação de tipografias no Brasil. O que se costuma apresentar como prova da intransigência lusa são documentos legais expedidos para atender a situações específicas de desrespeito às normas vigentes”.

O pesquisador chama a atenção para a utilização da imprensa em territórios portugueses. Nas terras portuguesas no Oriente, a imprensa desenvolveu-se à sombra dos missionários como estratégia para disseminar a religião e a língua materna; no Brasil não houve incentivo por parte do governo ou da Igreja, o que ocorreu mais por motivação econômica, em função dos custos de impressão e do moroso processo de liberação de licenças na colônia. Os jornais não eram vistos como um caminho contestador ou revolucionário, ou seja, não havia um temor quanto à imprensa 
e por essa razão Portugal abriu mão de estabelecer restrições jurídicas (MARQUES DE MELO, 2003, p.99).

As proposições até aqui descritas têm como base as visões dualistas para fundamentar o atraso na chegada dos periódicos ao Brasil: um território com burguesia e jornais ou sem uma classe dominante e com jornais; ou ainda uma colônia censurada e sem jornais versus uma colônia livre e com jornais. Os eixos das explicações residem em fatores econômicos ou políticos: o capitalismo como desencadeador da imprensa ou o impedimento legal como causas preponderantes. Entretanto, somente as questões políticas e econômicas não contribuem por si só para a compreensão abrangente do processo de implantação tardio da imprensa brasileira.

Na primeira tese brasileira de Jornalismo, de autoria de Marques de Melo (2003, p.87), encontra-se um eque de explicações de naturezas variadas para o nascimento dos primeiros jornais do Brasil Colônia. Alinhavando uma série de acontecimentos econômicos, políticos e sociais, denominados fatores socioculturais, o autor sintetizou em sete fatos históricos as raízes do retardamento da imprensa: natureza feitorial da colonização; atraso das populações indígenas; predominância do analfabetismo; ausência de urbanização; precariedade da burocracia estatal; incipiência das atividades comerciais e industriais, e por fim o reflexo da censura e obscurantismo metropolitanos.

Para identificar as condições necessárias de existência da imprensa na sociedade colonial brasileira, somos impelidos a admitir, como premissa básica, que o retardamento não se explica por uma única causa (política ou econômica), mas por um conjunto de circunstâncias causais, que se inter-relacionam e se influenciam mutuamente (...) Correspondendo a aspectos estruturais da Sociedade e da Cultura Brasileira, tais fatores marcaram profundamente a evolução do país, subordinando-a a um processo de mera atualização histórica (MARQUES DE MELO, 2003, p.112).

O primeiro fator a contribuir para o atraso na implantação das atividades tipográficas, conforme Marques de Melo (2003, p.113), foi a ocupação do território brasileiro, onde ocorreu uma transferência quase forçada de pequenos contingentes populacionais, sem praticamente ônus para a Coroa Portuguesa, que não desejava instalar na colônia cidades ou estruturar melhores condições de vida. A exploração econômica, comandada por particulares, aconteceu à margem de um povoamento lento e com poucas incursões pelo interior.

Dedicando-se às terras ultramarinas da África e Ásia, a Coroa deixou o território brasileiro isolado e sem ser sistematicamente inexplorado por quase três séculos, enxergando-o 
como uma boa reserva sem grandes atrativos para o futuro. O imenso território, habitado por populações na idade da pedra e com uma única riqueza inicial, o pautbrasil, não despertou de imediato o interesse comercial das autoridades. De acordo com Buarque de Holanda (1978, p.12), os empreendimentos nos trópicos não ocorreram de forma metódica e racional, pelo contrário, o abandono e o desleixo estiveram por trás das primeiras tentativas de ocupação.

A cobiça dos estrangeiros - os franceses e holandeses comandaram tráfico intenso no litoral - despertou o receio dos portugueses em perder as terras descobertas por Cabral. Outras nações européias, em franca expansão comercial (Holanda, França e Inglaterra), pressionavam Portugal e Espanha a se apossarem dos novos territórios. À defesa do território, instituirse a estratégia da colonização do extenso litoral através das capitanias hereditárias, adotando o mesmo procedimento utilizado na colonização dos Açores e da Madeira, legando à iniciativa privada uma atribuição financeira que a Metrópole não suportaria (PRADO JÚNIOR, 1993, p.13).

Em um contexto com fraco desenvolvimento econômico, a implantação da imprensa esbarrou ainda na cultura indígena incipiente (MARQUES DE MELO, 1997, p.116). O analfabetismo da maioria da população da colônia firmoutse como outro entrave ao desenvolvimento da imprensa. Numa cultura em que o verbal tomava o espaço da cultura escrita, as tipografias não tiveram vez. Acomodando-se às condições locais, o verbal transformou-se em indispensável instrumento de propaganda ideológica.

A falta de urbanização e a vida predominantemente rural apresentavam-se como outros obstáculos, estancando o crescimento econômico da colônia portuguesa. A vida resumia-se às fazendas de engenho e seus habitantes tinham uma postura quase reclusa e produziam para a própria subsistência; conviviam com um tímido comércio e um reduzidíssimo funcionalismo. Caracterizada pela existência dos latifúndios, a estrutura econômica da colônia, como explica Prado Júnior (1993, p.19) era composta por um fraco mercado interno, precárias condições de comunicação e custos altos para compra do rústico maquinário usado na produção do açúcar.

Calcada nas propriedades particulares, a ocupação das terras brasileiras fezse com intervenções à distância do governo lusitano através do Conselho Ultramarino (MARQUES DE MELO, 2003, p.133). A burocracia estatal, através da circulação de impressos (notas, formulários, tabelas de preços), não existiu na colônia, que permaneceu entregue ao marasmo econômico. Sem atividades fabris ou industriais, corroboradas pela fraca presença da administração pombalina, as capitanias não apresentavam as condições para suprir as demandas de uma imprensa regular. 
Sem o pulso firme dos governantes portugueses no comando da ocupação, desencadeout se um fraco desenvolvimento comercial e industrial. Nesse cenário, no qual não circulavam bens, informações e idéias, os jornais não teriam como se sustentar vislumbrando uma fugaz economia. "Não havendo necessidade dos usuais expedientes burocráticos-mercantis (...) pelo primitivismo dos métodos comerciais imperantes e pela atuação precária da máquina estatal, a imprensa não teria utilidade maior em terras brasileiras"(MARQUES DE MELO, 2003, p.136).

Consideramos que os ataques da Coroa às tentativas de implantação de tipografias concorreram também para atrasar a vinda dos impressos, embora isso não simbolize o principal obstáculo à proliferação dos jornais no Brasil, ao contrário da análise de Bahia (1972, p.14). Não existia uma legislação específica, ou seja, uma perseguição sistemática e organizada juridicamente. A postura de Portugal, de submeter suas colônias à censura, se assemelha a de outros governos nacionais europeus, que subjugaram a imprensa, utilizando-a enquanto caminho para defender seus interesses políticos ou econômicos.

A censura e o obscurantismo ocorriam também em Portugal, detentor de uma imprensa pobre e atrasada, alvo das restrições estatais e eclesiásticas, sabotadoras de iniciativas para o desenvolvimento do setor (MARQUES DE MELO, 2003, p.138). A Metrópole, nação retrógrada e conservadora, da mesma forma que obstruiu as atividades tipográficas, não instalou escolas e universidades no Brasil. O país emergiu em 1808 para um patamar econômico melhor, porém com a maior parte da sua população analfabeta e excluída.

De que acordo com Marques de Melo (2003, p.94-95), cronologia da chegada da imprensa ao território ocorreu da seguinte maneira:

\section{QUADRO 1}

\begin{tabular}{|l|l|}
\hline \multicolumn{1}{|c|}{ Estado } & \multicolumn{1}{c|}{$\begin{array}{c}\text { Ano de funcionamento regular } \\
\text { de atividades de impressão tipográfica }\end{array}$} \\
\hline $\mathbf{1}^{\mathbf{a}}$ fase & 1808 \\
Rio de Janeiro_ & 1811 \\
Bahia_ & 1821 \\
\hline $\mathbf{2}^{\mathbf{a}}$ fase & 1821 \\
Pernambuco_ & 1821 \\
Maranhão__ & 1821 \\
Pará____ & 1824 \\
Minas Gerais__án &
\end{tabular}




\begin{tabular}{|c|c|}
\hline Paraíba_ & 1826 \\
\hline São Paulo_ & 1827 \\
\hline Rio Grande do Sul_ & 1827 \\
\hline Estado do Rio & 1829 \\
\hline Goiás_ & 1830 \\
\hline Santa Catarina & 1831 \\
\hline Alagoas_ & 1831 \\
\hline Rio Grande do Norte & 1832 \\
\hline Piauí_ & 1832 \\
\hline Sergipe & 1832 \\
\hline Espírito Santo & 1840 \\
\hline Mato Grosso_ & 1840 \\
\hline Paraná_ & 1849 \\
\hline Amazonas_ & 1852 \\
\hline
\end{tabular}

Fonte: Marque de Melo (2003)

No início do século XIX, acontecimentos políticos na Europa - as guerras napoleônicas forçam a transferência da família Real de Lisboa para o Rio de Janeiro, processo desencadeador de uma transformação político-administrativa na colônia. Acossado pelo governo inglês, interessado nos mercados americanos, D. João VI tomou medidas econômicas - entre elas a abertura econômica, construção de estradas, fundação do Banco do Brasil e liberação das indústrias - que preparam o terreno para a autonomia brasileira frente a Portugal, como explica PRADO JÚNIOR:

Estabelecendo no Brasil a sede da monarquia, o regente aboliu ipso facto o regime de colônia em que o país até então vivera. Todos os caracteres de tal regime desaparecem, restando apenas a circunstância de continuar à sua frente um governo estranho. São abolidas, uma atrás da outra, as velhas engrenagens da administração colonial, e substituídas por outras já de uma nação soberana. Caem as restrições econômicas e passam para um primeiro plano das cogitações políticas do governo os interesses do país. (PRADO JÚNIOR,1993, p.47).

De território ignorado, explorado pela iniciativa privada, à sede da Corte, com o status de Reino Unido a Portugal e Algarves, o Brasil passou a ser prioridade ao Regente português, que defendeu os interesses nacionais e desejou instalar-se definitivamente no país, distanciando-se das forças políticas em luta na Europa, representadas por democratas e absolutistas. D. João VI não esperava despertar o nacionalismo na colônia, expresso na Revolução Pernambucana, em 
1817, e a pressão dos liberais na Revolução do Porto, cuja principal conseqüência foi o retorno da Corte a Lisboa (OLIVEIRA MARQUES, 2006, p.446).

Quatorze anos após a chegada da Família Real, o Brasil é proclamado independente após um processo de embates políticos entre partidários dos portugueses e brasileiros, entremeado por tentativas de recolonizar o território, pela desobediência de Dom Pedro à exigência de retorno a Portugal e sua proclamação como imperador. Nessa ebulição política e na sucessão de acontecimentos entre 1821 e 1823, o jornalismo brasileiro, nascido com o polêmico Correio Braziliense e a oficiosa Gazeta do Rio de Janeiro, desbravou seus primeiros desafios.

Para compreendermos a imprensa nascente e suas características, nos apoiaremos nas reflexões de Lustosa (2000) e Morel \& Barros (2003), porque essas proposições complementam as expostas por Marques de Melo (2003) ao abordar a chegada da imprensa enquanto um fenômeno advindo do processo histórico, resultado do encadeamento de questões socioculturais, perspectiva distante de explicações políticas e econômicas, que simplificam os acontecimentos e a intrincada relação entre os sujeitos envolvidos.

Os impressos do período da Independência surgiram sob as rusgas entre liberais e conservadores, adversários do pacto colonial e os defensores da dominação portuguesa. Tendo como pano de fundo as discussões políticas tão polarizadas, as principais capitais viram multiplicarem-se as folhas "incendiárias", assinadas por brilhantes jornalistas, debatedores das causas públicas da primeira metade do século XIX, como Cipriano Barata, Silva Lisboa, Luis Augusto May e Evaristo da Veiga, que ao lado de redatores anônimos, alimentaram as discussões sobre o destino nacional, conforme afirma Lustosa (2003, p.32-41).

Esses panfletos incendiários surgiram comprometidos com o processo revolucionário, assinala a mesma autora (2000, p.25-26), pois no avanço da separação entre Colônia e Metrópole, os jornais vão abraçando a causa brasileira e abandonando a postura de louvor à Coroa: o tom brando cederá lugar à investida agressiva, à defesa aguerrida dos interesses nacionais. Uma profusão de cidadãos opina nos impressos, de cores políticas as mais variadas.

Erguiam-se e confundiam-se as vozes dos intelectuais, dos políticos envolvidos diretamente com o modelo político que se estava superando, dos liberais exaltados, maços ou não, com as dos aventureiros de ocasião, dos arrivistas e dos que apenas se aproveitavam daquelas agitadas circunstâncias para se lançar na recém-criada profissão de jornalista (LUSTOSA,2000, p.25-26)

Os jornalistas assumem no contexto da emancipação política brasileira o papel de educadores, de iluminados, capazes de conduzir o povo ao progresso (LUSTOSA, 2000, p.33). O 
intelectual, antes quase inexistente no tempo da colônia isolada, é visto como o mentor da sociedade e volta-se para os impressos, palco das suas ações e idéias. Com uma linguagem mais simples e direta, leva o debate político para o público em geral e com o direito ao anonimato ousaram mais em seus escritos frente às contradições da Independência.

Ao passo que se descortina o jogo político, os jornais do princípio da imprensa brasileira buscavam nos leitores das camadas mais baixas adesões aos seus posicionamentos sobre a crise que se avizinhava. Se do ponto de vista editorial os argumentos ganhavam contornos definitivos interesses lusitanos ou brasileiros - o conteúdo jornalístico se livrava do rebuscamento, do palavreado difícil. É emblemático que um espaço intermediário entre a linguagem literária e culta vai sendo valorizado, configurando-se uma linguagem pública que se consolidou nas fases seguintes da imprensa nacional (LUSTOSA, 2000, p.36).

Morel \& Barros (2000, p.43-44) argumentam que os momentos que antecederam a independência brasileira e seus desdobramentos caracterizavam-se pelo hibridismo político, em que se mesclavam relações arcaicas - como escravidão e o absolutismo português - e as aspirações liberais, um projeto de país com liberdades civis, livre mercado e respeito à propriedade privada. Para os autores é no seio da imprensa, no período entre 1820 a 1830 , à sombra das divergências políticas, que emergiu a opinião pública brasileira:

Essa visão percebia no nascimento da opinião um processo pelo qual se desenvolvia uma consciência política no âmbito da esfera pública. Diante do poder absolutista, havia um público letrado que, fazendo uso público da Razão, construía leis morais, abstratas e gerais, que se tornavam uma fonte de crítica ao poder e de consolidação de uma nova legitimidade política. Ou seja, a opinião de peso para influir nos negócios públicos, ultrapassando os limites do julgamento privado (MOREL\& BARROS, 2000, p.22).

O momento crucial para a formação da opinião pública concentra-se entre 1820-1821, contexto da Independência do Brasil e de mudanças na estrutura política de Portugal. A imprensa periódica consolida-se com o crescimento de jornais em todo o país, além da circulação de manifestos, proclamações, denúncias e brochuras, incentivados pela liberdade de impressa, decretada em 21 de setembro de 1820 pela Junta de Governo da revolução constitucionalista no Porto.

Mesmo com uma população formada em sua maioria por negros escravos e analfabeta, a imprensa periódica colaborou ao publicizar a opinião nas ruas, praças e pequenos comércios. 
A imprensa pré-independência apresenta-se com feições moldadas por fatos históricos, defendendo ou atacando projetos políticos com uma linguagem mais acessível e veemente. Seu conteúdo configurava-a como mais doutrinária e informativa, tendo se propagado com rapidez nos principais núcleos de poder (Rio, Bahia, Pernambuco e Maranhão). É notável, segundo Morel \& Barros (2000, p.47), "o nascimento de uma opinião pública, e não mais de imprensa ligada exclusivamente à Coroa".

Se entre os séculos XVI e XIX, o jornalismo brasileiro foi sufocado por causas socioculturais, da ocupação lenta ao obscurantismo português, sua gênese irrompeu pelos acontecimentos ocorridos desde 1808 a 1823 . A política titubeante da Coroa, os ventos liberais na Europa, a urgência da emancipação brasileira e a nova ordem econômica desencadearam um ambiente favorável à existência dos periódicos, que foram delineando a identidade inicial do jornalismo brasileiro. Classificada como artesanal por Sodré (1999) e panfletária (MOREL \& BARROS, 2003), a primeira fase da imprensa periódica, segundo as reflexões dos autores, acena para as seguintes feições: tecnicamente rudimentar, opinativa do ponto de vista jornalístico e à sombra de uma liberdade de expressão em risco.

\subsection{A imprensa no Maranhão, um território autônomo}

Tendo como marco teórico principal desta pesquisa a obra de Marques de Melo (2003), que descortinou os fatores socioculturais responsáveis pela chegada tardia das atividades tipográficas no Brasil, exporemos a seguir as particularidades desse processo no Maranhão, estado autônomo, criado em 1534 e separado do Brasil desde 1621.

A província maranhense - em determinados períodos ao longo dos séculos XVII, XVIII e XIX - sofreu alterações em sua estrutura administrativa, à conveniência das autoridades portuguesas, o que denota que seu processo de ocupação, desenvolvimento econômico e projetos políticos guardam singularidades que o Reino do Brasil não conheceu, embora ambos os territórios estivessem sob a tutela da mesma Metrópole.

Com a finalidade de esclarecer os fatores do retardamento da imprensa na cena maranhense, propomos quatro eixos: a) Economia b) Política c) Sociedade e d) Cultura. Para detalhá-los, partimos do entendimento de que esse processo não pode estar enraizado em uma causa única, como investigou com propriedade Marques de Melo (2003), ao tecer o entrelaçamento entre razões econômicas, políticas, culturais e sociais. Para explanar as causas socioculturais no Maranhão, que se influenciam mutuamente, nos apoiamos ainda na produção científica de pesquisadores maranhenses e nas obras de referência sobre a História brasileira, 
porque apresentam contribuições significativas para a compreensão do fenômeno. Seguem os fatores socioculturais, que reúnem questões econômicas, sociais, culturais e políticas da cena maranhense, pontuados pelo marco teórico referido anteriormente.

\section{A chegada tardia da imprensa ao território maranhense: causas socioculturais responsáveis pelo retardamento}

\subsection{Causas políticas}

\section{Administração débil}

As constantes denominações do Estado do Maranhão dão pistas de uma política administrativa débil e sem uma direção firme dos negócios. Pendendo ora para o abandono e para a excessiva centralização, as medidas do governo lusitano desenharam um frágil projeto político que colaborou para um povoamento tardio, um lento crescimento econômico e conseqüentemente para a vinda atrasada das letras impressas. As principais medidas adotadas nos três primeiros séculos de ocupação da colônia - as capitanias hereditárias, as companhias de comércio e a abertura da economia com a vinda da Corte Portuguesa em 1808 - estiveram relacionadas às conjunturas favoráveis no mercado externo e não refletem medidas administrativas consistentes.

\section{QUADRO 02}

\section{Divisões administrativas do Maranhão}

\begin{tabular}{|ll|}
\hline Ano & Abrangência \\
\hline 1621 & Estado autônomo do Maranhão (MA, PA e CE) \\
\hline 1652 & Extinto Estado do Maranhão \\
\hline 1654 & Estado maranhense restaurado \\
\hline 1656 & Território perde região do Ceará \\
\hline 1700 & Piauí é integrado ao MA e PA \\
\hline 1774 & $\begin{array}{l}\text { Divisão do Estado do Maranhão e Grão-Pará em dois governos } \\
1811\end{array}$ \\
\hline 1823 & Piauí se separa do Maranhão \\
\hline
\end{tabular}

Fonte: Lacroix (2002), Libermann (1983), Lima (1981) e Chambouleyron (2005). 
O primeiro regime para defender-se de inimigos e dinamizar as relações econômicas no litoral, as capitanias hereditárias, foram gradativamente extintas até o governo pombalino e resultaram em fracasso na capitania Maranhão, criada em 1534 (SILVEIRA, 2001, p.35). A capitania não foi ocupada de imediato pelos proprietários, João de Barros, Fernand'Álvares de Andrade e Aires da Cunha. O grupo enviou frotas e colonos para povoá-la, mas as dificuldades de acesso e a resistência dos índios contribuíram para o abandono da capitania.

Eis os motivos que obstruíram o êxito do empreendimento português no Nordeste:

Nenhuma empresa particular poderia arcar com o ônus de tão vasto empreendimento como o de tornar efetiva a ocupação de dezenas de léguas de costa. O que se deu em todas ou quase todas as capitanias foi a dissipação imediata da totalidade dos capitais destinados à colonização e conseqüentemente impossibilidade do seu empreendimento (PRADO JÚNIOR, 1993, p.13).

No século XVII, a Coroa tomou para si as rédeas da vida colonial e criou os centros autônomos, a exemplo do Maranhão e Grão-Pará, subordinados diretamente a Lisboa. A Coroa empunha suas decisões a partir das ações de go vernadores nomeados, galvanizados pela antipatia da população. Na primeira metade do século XVII, cedeu às pressões da Igreja Católica, proprietária de grandes fazendas e detentora de escravos indígenas. A pobreza, o abandono e as pretensões do Santo Ofício no Maranhão engendraram conflitos sociais. Nesse cenário, a Coroa portuguesa tombava com suas decisões políticas inseguras e contraditórias.

Primeiro relegou ao abandono o Norte, só acordando um século depois do descobrimento, com a invasão francesa. (...). Tudo era centralizado, completamente dependente do Conselho Ultramarino, não havia uma legislação ordenada, não se entendiam os governantes, nem se estimavam governadores e povo, generalizando-se os conflitos entre leis e autoridades, a cobiça a todos inflamava, e, no terreno religioso, mal disfarçada pelo tão enaltecido apostolado, compulsava os sacerdotes uns contra os outros. (LIMA, 1981, p.76).

Destaca-se a criação das companhias de comércio, efetivadas no século XVII com a finalidade de somar dividendos para o governo português. É época de restrições à economia colonial, o comércio da colônia com outros países é vetado em 1661, e em 1684 os navios saídos do Brasil são proibidos de atracar em portos que não sejam os lusitanos. As companhias de comércio detinham a exclusividade da importação e exportação, o estanco de alimentos e o monopólio do pau-brasil. O estanco significou o monopólio do governo português no fornecimento de gêneros e escravos para São Luís; em contrapartida os colonos deveriam vender 
toda a sua produção à Coroa. No Maranhão, a companhia de comércio foi coberta de mais privilégios, todo o fornecimento de produtos ficou a cargo da companhia, sem restrições. Para Caio Prado Júnior (1993, p.36-37), “o regime das companhias foi lamentável para os interesses da colônia". Sob o regime dessas instituições a economia da colônia não prosperou e seus dirigentes defenderam interesses particulares, bem diversos dos interesses dos colonos, alvo de abusos e práticas desleais.

No século XVIII, os empreendimentos portugueses - o Brasil e os centros autônomos "se interligavam, se bem que de maneira fluida e imprecisa, através do extenso hinterland pecuário" (FURTADO, 2002, p.90). A bonança econômica não costumava atingi-los da mesma maneira. É notável que no final dos anos 1700, o território do Maranhão tenha atravessado um período de crescimento, motivado por sua intensa produção algodoeira e as demandas da Revolução Industrial, tratando-se praticamente do primeiro surto econômico desde sua fundação. O mesmo não aconteceu com o Estado do Brasil, que atravessou depressão econômica com a desvalorização do ouro e dificuldades na região pecuária. A situação é alterada com as medidas de Dom João VI após a transferência da Corte para o Rio e a abertura da economia (FURTADO, 2002, p.91).

O progresso econômico maranhense concretizou-se sob uma nova companhia de comércio, desta vez revigorada pela gestão pombalina, em 1755. No entanto, não atingiu 30 anos de serviços, sendo extinta por D. Maria I, em 1778. Sustentada pelo algodão e o açúcar, com elevados preços no mercado externo, os produtos maranhenses geraram lucros e dívidas até meados de 1820, quando a produção de algodão norte-americana foi retomada. Após a nova debilidade, a economia soergueurse entre 1850-1870. Persistiram, contudo, as dificuldades da economia agrícola:

O lavrador maranhense não tratou de modernizar seu padrão antiquado de produção, organizando o trabalho conforme a mentalidade capitalista prevalecente no mundo. A resistência senhorial parece que obnubilou agricultores e comerciantes otimistas quanto à perenidade daquela riqueza fugaz, sem levar em conta a estrutura do sistema produtivo e sua dependência de fatores externos. (LACROIX, 2002, p.71)

A abertura econômica em 1808, o tratado de comércio com a Inglaterra de 1810 e a enxurrada de produtos daquela nação no mercado interno brasileiro alteraram a fisionomia da economia e colocaram a colônia no raio de influência britânica. Atordoada com os acontecimentos na Europa, a invasão de Lisboa pelos franceses e as pressões de Napoleão, a 
Metrópole cedeu ao governo inglês e promoveu reformas econômicas. Furtado (2002, p. 32) analisou a questão: "Portugal compreendeu, assim, que para sobreviver como metrópole colonial deveria ligar o seu destino a uma grande potência, o que significaria necessariamente alienar parte da sua soberania".

Novamente atropelado pelo contexto internacional e sem posição firme frente às questões econômicas e políticas, o governo português deu um golpe de morte em sua própria economia deflagrando a abertura dos portos e o fim do seu monopólio no fornecimento de manufaturas ao Brasil ao se tornar importador das mercadorias vindas de portos ingleses. Em plena revolução industrial e com os mercados europeus fechados em função dos conflitos e pendências políticas, a Inglaterra vislumbrou nos territórios lusitanos os novos consumidores de suas mercadorias (FURTADO, 2002, p.35).

A engrenagem do sistema colonial, sintetizada no monopólio comercial, vai sendo posta abaixo. As restrições econômicas caem e mobilizam a elite portuguesa na defesa dos seus interesses, movimento expresso na Revolução do Porto, de 1817, e nas tentativas de reordenar o jogo de forças e trazer o Brasil à condição de colônia e não de reino unido a Portugal. A abertura econômica, as melhorias na infra-estrutura do território, a montagem da burocracia estatal e as revoluções nas províncias favorecem a emancipação brasileira em 1822 e a construção da identidade nacional (PRADO JÚNIOR, 1993, p. 45).

A débil administração do território brasileiro por Portugal e a condução contraditória da economia e da política frearam o desenvolvimento da colônia, bem como o fomento das atividades fabris e industriais, sujeitas à preponderância da produção agrícola e aos interesses da aristocracia rural e da elite portuguesa. No Maranhão, a indefinição do papel do território na política econômica lusitana arrastou o centro autônomo ao marasmo, ao lento povoamento, aos desmandos de governantes e comerciantes e aos conflitos sociais, quadro amenizado pela valorização do algodão e do açúcar no exterior, no final do século XVIII. Anexado ao Brasil em 1823, após embates entre portugueses e brasileiros no reconhecimento da independência, o destino do Maranhão ficará atrelado às prioridades do governo brasileiro, suas vitórias e fracassos.

\section{Ocupação lenta do território}

O povoamento do Brasil foi um grave problema para Portugal (PRADO JÚNIOR, p.11, 1993). Como a princípio não apresentou um leque de riquezas que pudesse competir com as possessões portuguesas no Oriente, o território ficou praticamente abandonado, registrando-se 
poucas incursões portuguesas no século XVI. No extremo norte do Brasil, no Maranhão, a cena não foi diferente, no entanto a cobiça de franceses e holandeses os instigou a movimentar o litoral e promover o tráfico de produtos tropicais, inaugurando as primeiras manifestações mercantis no lugar. Os primeiros contatos entre estrangeiros e índios datam de 1594, em expedição chefiada por Jacques Riffault.

A origem do nome Maranhão não é conhecida e são apresentadas várias justificativas. César Augusto Marques, na obra Dicionário sobre a Província do Maranhão, explica que o nome pode estar relacionado a um descobrir português, pois o termo aportuguesado Maragnon era comum na Península Ibérica (apud LIBERMAN, 1983, p.17). Outra possível explicação vem da língua ferina do Padre Antônio Vieira, superior das missões jesuíticas, que chegou ao Maranhão em 1653, foi preso e expulso em 1661 após uma insurreição popular contra a concentração da mão-de-obra indígena nas mãos dos religiosos:

M de Maranhão significava murmurar, motejar, maldizer, malsinar, mexericar, mentir, Mentir com palavras, mentir com obras, mentir com os pensamentos e que no Maranhão até o sol é mentiroso, porque amanhecendo muito claro e prometendo um formoso dia, de repente e dentro de uma hora se toldava o céu de nuvens e começava a chover. (apud LIBERMAN, 1983, p.17)

Acossada pelos estrangeiros e relegada por Portugal, a possessão viu-se ocupada por franceses, liderados por Daniel de La Touche, o Senhor de La Ravardière, que, acompanhado por 500 homens, ergueu o Forte e a Vila São Luís em 1612 no ousado projeto França Equinocial, um empreendimento que não prosperou e tampouco promoveu o desenvolvimento econômico maranhense. Abortado por portugueses três anos depois, a França Equinocial naufragou com a expulsão dos franceses.

As invasões estrangeiras não cessaram no século XVII. Mais um exemplo foram as tropas holandesas, chefiadas por Maurício de Nassau, que invadiram o Maranhão, desta vez em 1641, sendo expulsas pelos portugueses. Como explicou Lago (2001:67): “apareceram na baía do Araçagi (...) fundeadas, 22 embarcações holandesas (...) e com a maior parte dos navios foi dar fundo defronte, donde hoje é a ermida do desterro, e desembarcando a tropa sem lhe oporem resistência, saquearam a povoação com vergonha e desonra do seu governador".

Mantendo o nome São Luís, a Coroa Portuguesa iniciou no século XVII uma ocupação lenta, sem um cronograma específico ou motivação econômica definida. O território, antes um quartel das tropas da Metrópole, começou a receber a primeira leva de colonos, cerca de 
200 casais e militares dos Açores no governo de Diego Machado da Costa (1619-1622) (VIVEIROS, 1954, p.15).

A ocupação morosa e limitada pela legislação portuguesa estancou o desenvolvimento econômico da colônia, que não atingiu sequer 1.400 habitantes em 1720, ou seja, quase cem anos depois a situação havia se alterado muito pouco. Com uma vida simples e sem atrativos, os colonos ocupavam-se de atividades burocráticas nos quartéis ou cultivavam mandioca ou algodão. Não havia comércio, nem moeda, nem o que vender ou exportar; a economia restringia-se à troca de gêneros (VIVEIROS, 1954, p.16). Nessa calmaria, o imenso território sofreu regimes administrativos, ora tinha autonomia, ora estava vinculado ao Estado do Brasil. O vai-e-vem jurídico ocorreu da seguinte forma (LACROIX, 2003, p.69): teve início com a Carta Régia de junho de 1621, que o considerou autônomo, com extensão do Rio Oiapoque ao Ceará; extinto em 1652, foi restaurado em 1654; perdeu o Ceará em 1656 e foi dividido em dois Estados, Maranhão e Grão-Pará em 1774.

QUADRO 03

Ocupação do território do Maranhão

\begin{tabular}{|c|c|}
\hline População - no de habitantes & Ano \\
\hline $400-480$ & 1648 \\
\hline 700 & 1658 \\
\hline 600 & 1662 \\
\hline 1000 & 1683 \\
\hline 78.860 & 1779 \\
\hline 160 mil & 1811 \\
\hline 210 mil & 1819 \\
\hline
\end{tabular}

Fonte: Lima (1981), Liberman (2003), Meireles (1994), Caldeira (2003)

Frente à letargia do território e à ausência de vantagens para o reino português, a imigração só foi fomentada no quarto governador, Muniz Barreiros. Com a intenção de lograr êxito no chamamento de interessados, optoutse por publicar um documento, Relação Sumária das Cousas do Maranhão: dirigida aos pobres deste Reino de Portugal, considerada a primeira peça de propaganda do Estado do Maranhão, de autoria de Simão Estácio da Silveira. A publicação, de 1624, ressalta os aspectos positivos da terra - suas águas límpidas, o solo e o clima - e descreve com generosidade as potencialidades do local: 
... vai o Maranhão cada dia em crescimento, e a terra mostrando sua fertilidade e fecúndia; e são feitas muitas roçarias de farinhas e outras culturas, e há já muitas casas de telha, muito boas olarias, muitas caças, pescarias, mariscos, frutas, mel, hortas, sal e lenha, e algumas criações e outras muitas cousas (...) só falta comércio de navios, em que homens se valham do que tiverem e hajam a troco o que lhes falta, que, como houver um navio na terra, logo começará a florescer e mostrar as grandezas de sua fertilidade (SILVEIRA, p.40, 2001).

Com o ímpeto de atrair mais colonos, a propaganda denunciou as fragilidades econômicas do território. A situação era de pobreza, como afirma Lima (p.74, 1981), pois "todos andavam descalços, os escravos nus, nas cidades e nas fazendas, as pessoas mais importantes com vestes de panos de algodão, tinturadas a preto. Em 61, famílias da nobreza deixaram de ir à missa de Natal, por não terem as moças o que vestir".

Em 1680, ao retornar ao Maranhão, o Padre Antônio Vieira reforçou a perspectiva das condições precárias no Estado, acenando para a possibilidade de descaso da Coroa:

o estilo ou pouco governo, com que se vive naquelas partes, porque exceto a cidade de São Luís do Maranhão, onde de poucos tempos para cá se corta carne algumas vezes, em todo o estado não há açougue nem ribeira, nem horta, nem tenda onde se vendam as coisas usuais para o comer ordinário (apud LIMA, 1981, p.75).

O povoamento lento do território maranhense transformou-se em um entrave ao desenvolvimento da província, ao passo que demorou a consolidar-se uma sociedade local a se ocupar de atividades econômicas, motores do crescimento do Estado. Sem uma ocupação sistemática retardoutse a presença permanente de representantes da administração central no ordenamento da vida dos habitantes e no incentivo à construção das primeiras cidades.

\section{Ausência de infra-estrutura}

A falta de infra-estrutura na capital maranhense e nos municípios da Província, caracterizada pela precária urbanização e as deficientes estradas, contribuiu para o retardamento do progresso econômico, o isolamento das comunidades, bem como dificultou a circulação de idéias e a mobilização social, fomentadores da opinião pública, cuja amplitude dos debates também mede-se pelos embates na imprensa.

O lento desenvolvimento econômico, pontilhado por progressos forjados a partir de contextos favoráveis no mercado externo, esbarrou no pouco interesse governamental em dotar o território de infra-estrutura. Lago (2001, p. 17) descreve de forma contundente o 
estado das vias que interligavam os municípios, no princípio do século XIX: "ponte não há uma só permanente, havendo tantos rios, e alguma que há, é de paus brutos, grosseiramente ligados por meio de cipós. Não é melhor o estado das estradas, que a todas podemos chamar de caminhos de vizinhança" (grifo do autor).

Verifica-se, como analisa Meireles (2001, p.256), que o modelo econômico sedimentado na exportação e na escravidão da mão-de-obra, adotado no Maranhão, concentrou os lucros das transações comerciais nas mãos de uma pequena elite econômica, que tampouco, espelhando-se no governo local, se interessou em dotar o território de boa infra-estrutura. Quando implantou projetos permanentes no sentindo de proporcionar melhorias nas localidades, tais iniciativas foram delimitadas a determinados espaços das cidades, deixando a maior parte da população excluída dos benefícios.

De acordo com Ribeiro Júnior (2001, p.63-64), as primeiras tentativas de promover o calçamento das ruas de São Luís ocorreram em 1804, mas a iniciativa não se concretizou porque se voltou no terceiro decênio daquele mesmo século a retomar o projeto, contudo restrito às áreas nobres da capital. Configura-se neste episódio a tendência de "segregação espacial na urbe ludovicense", como aponta o autor (2001, p.64). Os chamados códigos de posturas, organizadores da ocupação das áreas citadinas, foram implementados em São Luís somente na segunda metade do século XIX com o objetivo de ajustar a organização da capital. Data da mesma época a construção de estradas ligando o bairro central às periferias e a construção do Cais da Sagração, além da criação da Companhia das Águas de São Luís, de 1874, e o assentamento de trilhos para os bondes (RIBEIRO JÚNIOR, 2001, p.68).

Concentrando o fausto econômico no Maranhão, a capital São Luís, mesmo assim, somente amparou-se de uma via de expressiva importância apenas no século seguinte. A Estrada de Ferro São Luís-Teresina, que margeou o rio Itapecuru, foi inaugurada em 1921, contribuindo para a manutenção da cidade como ponto principal para escoamento da produção (RIBEIRO JÚNIOR, 2001, p. 76). Essa tendência, com veremos adiante, mudou com a implantação de projetos econômicos no interior do Estado e abertura de estradas federais, principalmente na segunda metade do século XX.

Meireles (1992, p.16) confirma que no começo dos anos de 1900 não havia rodovias no Maranhão e a Estrada de Ferro São Luís-Teresina, que custou cerca de 45 mil contos, era a única até então, situação que mostra o precaríssimo funcionamento das vias de comunicação. É notável nesse período as dificuldades atravessadas pelo Maranhão, com o fim da escravidão em 1888 e as mudanças políticas e econômicas desde a independência do Brasil. O Estado 
lentamente recompunha-se diante dos desafios advindos da adesão à emancipação brasileira e diante de todos seus desdobramentos.

No rastro da decadência econômica maranhense, retomamos Meireles (2001, p.306), em sua obra sobre a História do Maranhão, para registrar o comentário do autor a respeito das dificuldades enfrentadas pelo governo local durante as primeiras quatro décadas da vida republicana. Um fato, sublinhado pelo historiador, ilustra a queda do Estado no quesito economia, refletindo-se na infra-estrutura oferecida à população:

Nossa capital que fora das primeiras cidades, em todo país, a servir-se de iluminação a gás e de transporte urbano a tração animal, e seria das últimas, dentre a nossas metrópoles estaduais e cidades maiores, a poder substituir esses serviços de utilidade pública, quando caíram em desuso, pelos de iluminação e tração elétricas MEIRELES (2001, p.306).

No caso do Maranhão, o crescimento das cidades tem ligação direta com o surgimento da imprensa. Na povíncia, as localidades que apresentaram relativo crescimento econômico e desenvolvimento social - como urbanização e estruturação de serviços públicos, foram as que conheceram pioneiramente as atividades tipográficas: São Luís, Caxias, Viana, Codó e Barra do Corda - situadas nas regiões Norte, Leste e Oeste (SILVA, 1981). Mas a ausência dessas melhorias e a predominância de uma população rural e atrasada obstacularizaram a chegada dos impressos em outras cidades maranhenses.

\section{Obscurantismo da Coroa Portuguesa}

Para não atiçar idéias contrárias ao império português no continente americano, a administração central permaneceu vigilante quanto à circulação de jornais e livros em suas colônias. Se não instaurou uma rígida legislação e punições contra aqueles que desejavam fazer circular impressos em seus territórios americanos, tampouco ficou indiferente ou quis incentivar a implantação de tipografias, como analisa Marques de Melo (2003, p.140). O pesquisador aponta o reflexo da censura e do obscurantismo metropolitano como uma das causas socioculturais responsáveis pelo retardamento da chegada da imprensa ao Brasil:

A inexistência de tipografias no Brasil constitui um reflexo da censura estatal e eclesiástica que deveria ser mais rigorosa aqui, principalmente pela sua situação de dependência política. A eclosão, no fim do século XVIII, de alguns movimentos emancipacionistas, tornaria muito mais intensa a repressão lusitana, considerando ademais que já campeavam em territórios portugueses, quer da Europa que da América. (MARQUES DE MELO, 2003, p.141). 
Em seu estudo aprofundado sobre o assunto, Marques de Melo (2003, p. 144) contextualiza a pobreza da imprensa periódica de Portugal à época em que essa atividade se desenvolveu naquele país, um caminho para entendemos também o pouco interesse das autoridades em multiplicar as folhas noticiosas em seus potentados americanos. As apreensões registradas em Recife, em 1706, e no Rio de Janeiro, em 1747, evidenciam o quanto as autoridades portuguesas monitoravam a atividade impressa, cercando de um controle expressivo.

No Maranhão, as obras de referências a que tivemos acesso não se referem a casos de tentativas de implantação da imprensa antes do século XIX, quando o governo importou a primeira tipografia. Note-se que o território ficou isolado e com população escassa até meados do século XVIII, com uma sociedade rarefeita e sem condições de acender a opinião pública. Até então com comércio inexpressivo, o território maranhense verá, por meio da implantação da Companhia de Comércio do Grão-Pará e Maranhão, como diz Meireles (2001, p. 256), um panorama de prosperidade o qual "se traduziu no enriquecimento material e no aprimoramento intelectual da sociedade, e culminaria, já no Império, no surgimento de uma elite latifundiária e de uma nobreza rural que concederiam à então província uma oposição de primeiro plano no cenário nacional".

Não foram formalizadas proibições legais no território maranhense que impediram a proliferação de tipografias, de acordo com os documentos do Catálogo dos Manuscritos Avulsos Relativos ao Maranhão existentes no Arquivo Histórico Ultramarino, que compreende um conjunto volumoso de atos relativos à administração portuguesa no Estado do Maranhão até o século XIX. Foram encontradas informações relacionadas à fidelidade de $O$ Conciliador ao monarca português, à utilidade da tipografia e à Gazeta Extraordinária, que circulou em substituição ao primeiro jornal, sem referências, no entanto, de apreensões de maquinários (BOSCHI, 2002). Tampouco encontramos indicações relativas de censura às tipografias em solo maranhense nos tomos referentes às leis estaduais no século XIX. Nessa centúria, há informações sobre contratos com a Tipografia Maranhense através da Lei ${ }^{\circ} 444$, de 06 de setembro de 1856, para atos oficiais, e a Lei $\mathrm{n}^{\circ}$ 612, de 23 de setembro de 1861, que diz respeito à Sociedade Beneficente dos Ourives e à Tipografia Maranhense, contempladas com uma loteria no valor de 20 contos de réis cada uma.

Esse indício confirma a leitura de Marques de Melo (2003, p. 138) de que não havia uma perseguição sistemática às iniciativas de implantar a imprensa na colônia, mas instrumentos foram criados para barrar o desenvolvimento dos impressos, já que "nenhum livro ou 
publicação circulava no Reino ou nas colônias sem obter a necessária autorização dos órgãos censórios, quer em relação aos impressos em territórios portugueses, quer em relação aos importados de outros países" (MARQUES DE MELO, 2003, p. 138).

O peso da censura oficial, para Lustosa (2003, p. 07), foi o maior empecilho para a chegada da letra impressa, que resultava na proibição de tipografias, contudo acreditamos que essa questão conjugou-se com as demais causas socioculturais apontadas e não atuou de forma isolada, ocorrendo, por conseguinte, um entrelaçamento de fatores sociais, econômicos e políticos, principalmente. A autora enfatiza que a presença da imprensa tornourse obrigatória com a vinda da Família Real: "também havia a necessidade de se fazer imprimir os atos do governo e de divulgar notícias interessantes à Coroa. Daí ter-se implantado aqui também, logo após a chegada do rei, a imprensa" (LUSTOSA, 2003, o.p. 8).

Se a repressão portuguesa não constituiu a explicação principal por desencadear o processo de retardamento da imprensa no Maranhão, ela por sua vez, deu o ritmo do surgimento das primeiras tipografias maranhenses. Como informa Serra (2001, p.21), a Tipografia Nacional Maranhense, fundada por iniciativa do governo da província, "até 1830 foi (...) a única imprensa que possuiu a província. Depois da Independência passou a denominar-se de Tipografia Nacional Imperial". Por quase dez anos foi a primeira e única a editar suas obras, situação que alterourse com a emancipação política, o que sinaliza que o progresso foi lento e gradual das tipografias em solo maranhense.

Sobre as tentativas de romper com o controle português quanto à publicação de folhas noticiosas e o acesso aos livros nas cidades maranhenses, podemos afirmar que há silêncio dos pesquisadores sobre esse momento histórico, sendo necessário jogar novas luzes sobre a história da imprensa local, abordando não somente os acontecimentos celebrados pela memória oficial, como também trazendo à tona os fatos históricos que contrariaram o poder político instituído.

\subsection{Causa Econômica}

\section{Modelo econômico dependente de fatores externos}

No Maranhão do século XVII, os únicos lugares não ameaçados pela penúria eram as propriedades da Companhia de Jesus, exportadora de cacau, baunilha e cravo. O número de jesuítas foi aumentando gradativamente desde a chegada do padre Antônio Vieira e outros 
missionários, em 1543, quando o superior da ordem dos jesuítas viajou ao Maranhão com a finalidade de restaurar as missões, ameaçadas por embates com índios, mortes e naufrágios na região. Novos eclesiásticos aportaram entre 1657 e 1659. Nessas levas foram organizadas as principais ordens eclesiásticas a trabalharem na conquista dos habitantes do Maranhão: Carmo, Mercês e Santo Agostinho (VIVEIROS, 1954, p.27).

A atuação, os privilégios e a desenvoltura econômica da Companhia de Jesus despertaram a antipatia de colonos e governadores. As querelas envolvendo os jesuítas tornaram se mais freqüentes com a chegada do Padre Antônio Vieira e a disputa pela mão de obra indígena. Em uma terra de poucas oportunidades econômicas e de escassez de mão-de-obra, o braço indígena significava riqueza (LIMA, 1981, p.72). Os protestos contra a ordem econômica e a presença dos jesuítas - que ambicionavam se apoderar dos índios na região - resultaram na expulsão dos eclesiásticos em 1661 e 1684.

O quadro se agravou em 1684, quando foi liderado por Manuel Beckman - português, senhor de engenho do Mearim, de origem judaica não confirmada - o primeiro levante dos territórios portugueses na América contra a Metrópole (LIMA, 1981, p.85). Beckman, antes do episódio, exerceu o cargo de vereador e chegou a ser preso em função das críticas que fazia ao poder central. O repúdio aos religiosos, os desmandos do governador Sá e Menezes e os protestos contra o Estanco ou Fazenda Real fomentaram os revoltosos. No entanto, a Metrópole não cumpriu com suas atribuições, enviando alimentos de má qualidade e um número de escravos abaixo do prometido. Não só não honrou o acordo integralmente como repassou o monopólio para terceiros.

A criação da companhia não arrefeceu os ânimos e despertou desconfiança em decorrência da denúncia de favorecimentos. O quadro geral das motivações da insurreição remonta às péssimas condições econômicas desde a colonização.

Uma questão fundamental foi a expulsão do governador Francisco de Sá e Menezes que representou não apenas uma reação dos colonos contra sua pessoa, mas contra todos os dirigentes do Maranhão que anteriormente já haviam assumido atitudes abusivas do poder, com a finalidade exclusivamente de defender seus interesses pessoas e aumentar seus lucros (...) O fenômeno do estanco (...) foi a gota d'água que tornou explosiva a situação. $\mathrm{O}$ descontentamento era geral. (LIBERMAN, 1983, p.83).

A insurreição irrompeu em 24 de fevereiro de 1684 com o apoio do clero, da Câmara Municipal, dos senhores de engenho e do povo, e a formação de uma "Junta dos Três 
Estados", com representantes dos três estamentos da sociedade local, nobreza, clero e povo. A junta, que tinha a atribuição de governar a cidade, negou obediência ao governador, ordenou a expulsão dos jesuítas, o fim do estanco e a prisão de autoridades - do capitão mor Balthazar Fernandes, que governava em lugar de Sá e Menezes, do capitão e Juiz Manoel Campelo de Andrade e do capitão Antônio de Souza Soeiro.

O documento manuscrito "Proposta que fizeram os procuradores do povo sobre o governo da cidade de São Luiz do Maranhão pela privação que fizeram ao governador Francisco de Sá e Menezes", elaborado pelas lideranças da revolta, em 25 de Evereiro de 1684, sintetizou o estado lastimável da província: "Que o povo em rezão da opresão em que servião por falta de governo e asistencia dos governadores na sidade por rezidirem de annos a esta parte continuamente no Pará sem quem os governassem e זem defendese" (apud LIBERMAN, p. 1983, p.88).

O governo revolucionário no Maranhão teve a duração de 15 meses, sem a adesão de outras cidades e do vizinho Pará. Vitoriosa em São Luís, a revolta perdeu força sem lograr um apoio maior. Após as primeiras decisões, seus participantes foram presos ou degradados. Manuel Beckman foi delatado e enforcado em São Luís. A eclosão do movimento, apesar de não conseguir seu intento, ou seja, uma nova política econômica sem a opressão portuguesa e a intromissão dos jesuítas, resultou na abolição do estanco com o parecer das Câmaras de São Luís e Belém após sufocado o movimento.

As condições precárias da economia continuarão até a primeira metade do século XVIII. Nesse cenário, não circulava dinheiro amoedado; as trocas no comércio eram feitas com açúcar, tabaco, cacau, cravo, algodão e varas de pano (LIMA, 1981, p.92). Algumas medidas do governo português no sentido de melhorar a situação do território se verificaram em 1721, com a introdução da escravidão, e finalmente em 1732, quando foi autorizada a circulação de moedas de prata e ouro no Maranhão.

Independente do Brasil, em 1774, o Estado do Maranhão não agregou benefício nessa separação administrativa, tão frágil estava sua economia, em contraste com a do Estado brasileiro, que à época já amealhava certo desenvolvimento ao dispor da cultura do açúcar e tabaco. Mesmo assim, o Brasil enfrentava os trâmites quase intransponíveis da legislação lusitana, os empecilhos eram tantos à exportação de gêneros da colônia que os estoques acumulados corriam o risco de ser queimados. Para Viveiros (1954, p.68), as diferenças eram enormes entre Brasil e Maranhão, "naquele a ruína era pela abundância neste, pela escassez. Um abeirava-se da miséria por ter muito, o outro por não ter nada”. 
$\mathrm{O}$ atraso econômico avançou até o final do século XVIII, quando um breve salto econômico aconteceu entre 1780 e 1820, impulsionado pela administração de Marques de Pombal e a criação da Companhia Geral do Grão-Pará e Maranhão. Detentora de monopólio comercial em todo o Estado, a nova instituição despertou a desconfiança dos comerciantes e religiosos, ressabiados com a experiência lastimável da primeira companhia de comércio do século XVII, que gerou inquietações e provocou a revolta de Beckman. Sob protestos no Maranhão e no Pará, a companhia foi instaurada e representou o fim da era colonial, afirma Lacroix acentuando o cenário mundial favorável:

a Coroa investiu no Estado, ajudando a formar a Companhia Geral do Comércio do Grão-Pará e Maranhão, alavanca propulsora do crescimento econômico, auxiliada pelas mudanças de conjunturas internacionais, tais como os conflitos pela independência americana, as prolongadas guerras napoleônicas, as revoltas de escravos antilhanos, a desorganização da América espanhola em luta contra o colonialismo espanhol e, sobretudo, pela importação britânica do algodão, demandado pelas fábricas têxteis surgidas com a Revolução Industrial. (LACROIX, 2002, p.70)

Subordinada ao rei português e com direito de construir navios de guerra e mercantis, a Companhia Geral do Grão-Pará e Maranhão é vista como um marco pelos historiadores. Para Lima (1981, p.104), a Companhia "revitalizou as fontes produtoras de riqueza social, incrementou a produção e o consumo de gêneros tropicais de alta comercialização nos mercados europeus". Conforme Viveiros (1954, p.74), a Companhia desenvolveu as fontes da economia maranhense ao introduzir escravos a preços módicos e com pagamento em longo prazo; financiamentos para campos de lavouras; fornecer sementes para os colonos; entregar mercadorias para serem quitadas em um ano; estabelecer a navegação para Portugal e comprar mercadorias coloniais a preço justo.

A produção de algodão, arroz, milho e couros sustentou o desenvolvimento econômico e uma balança comercial positiva. Os mercados de Portugal, Inglaterra e Estados Unidos foram os principais destinos dos produtos maranhenses. No entanto, se a agricultura cresceu a passos largos, o mesmo não aconteceu com as atividades artesanais e industriais, que somente atendiam ao mercado interno e as regiões próximas. Essas atividades eram menos robustas frente à preferência dos colonos pela produção agrícola (CALDEIRA, 2003, p.44-45).

A pujança econômica na segunda metade do século XVIII e o ímpeto moralizador das finanças reais na administração pombalina incrementaram o tráfico negreiro no Maranhão 
com envio regular de escravos, que tinham como mercado certo as fazendas do interior. Negros de várias nações foram embarcados como mão-de-obra escrava em Bissau, Cacheu, Angola, Guiné, Cabo Verde, Serra Leoa e Costa da Mina (Costa do Marfim, Costa do Ouro, Costa dos Escravos, ilhas de São Tomé e Príncipe). Os primeiros contingentes de africanos chegaram a São Luís em 1680 em um total de 600. No século seguinte, a Companhia de Comércio do Grão-Pará e Maranhão engrossou o comércio trazendo para o Maranhão 12 mil escravos em 20 anos (VIVEIROS, 1954, p.85).

A prosperidade econômica maranhense, favorecida pelas condições no mercado internacional, engendrou transformações na sociedade local com o aumento da imigração; a abertura e calçamento de ruas; a construção de redes de esgoto. Incentivourse o cultivo as letras e artes, os filhos das classes mais abastadas vão estudar nas universidades portuguesas, inglesas e francesas como assinala Caldeira (2003, p.27). Cresceu a freqüência ao teatro e espetáculos públicos como em Paris, a capital do mundo, e o livro, antes uma raridade, circula em espaços privilegiados (LACROIX , 2002, p.60-61).

A riqueza efêmera debilitou-se nas décadas de 1820 e 1830 frente à retomada da produção algodoeira nos Estados Unidos, à diminuição dos lucros nas transações e à efervescência política, marcada pela emancipação política brasileira e do aparecimento dos jornais impressos. A chamada "crise econômica", delimitada pela retração dos negócios no exterior com a venda do algodão, é analisada por Assunção (2000, p. 55) não como uma derrocada do modelo econômico de então. Para o pesquisador o fenômeno representa a visão dos ricos produtores agrícolas, que chamaram de "decadência" o fato de serem obrigados a estreitar a margem de lucro e a promoverem a interiorização da economia.

Apesar das dificuldades, o crescimento econômico sedimentou as condições necessárias à implantação da imprensa no território maranhense: o soerguimento das atividades comerciais, o incremento do povoamento, a franca urbanização e o fortalecimento de segmentos sociais capazes de promover a circulação de idéias.

\subsection{Causas sociais}

\section{Pobreza da população}

As profundas diferenças sociais, calcadas na divisão econômica da província do Maranhão, marcaram o começo da sua colonização, fortalecida a partir dos anos 1600. Índios, 
portugueses e negros compõem a população maranhense e protagonizam inquietações, querelas e embates, ora como aliados, ora como antagonistas nos três primeiros séculos de ocupação. De acordo com dados da inglesa Maria Graham, que viajou pelo Maranhão em 1821 (apud CALDEIRA, 2003, p.19): dos empregados na produção agrícola, 78\% eram escravos (69.534) enquanto $22 \%$ correspondiam aos homens livres (19.960). Segue quadro com outros dados sobre a população total e suas condições sociais.

Quadro 4

Habitantes do Maranhão - 1821

\begin{tabular}{|l|l|l|l|}
\hline Condição social & População Total & $\begin{array}{l}\text { Trabalhadores na } \\
\text { lavoura }\end{array}$ & $\%$ \\
\hline Livres & 35.618 & 19.660 & $29 \%$ \\
\hline Escravos & 84.434 & 69.534 & $71 \%$ \\
\hline Total & 120.052 & 89.494 & $100 \%$ \\
\hline
\end{tabular}

Fonte: Graham (apud Caldeira, p. 20, 2003)

Lago (2001, p.25), em sua obra sobre as estatísticas histórico-geográficas da Província do Maranhão, apontou que as condições sociais eram precárias para as camadas pobres. Apesar do crescimento econômico, no final dos anos 1700, o quadro é crítico. Há grande mortandade de crianças e moléstias "que por diferentes modos abreviam a vida". Sobre os escravos, ainda conforme o autor, as atribulações são mais pesadas, "miséria, vício e castigo, pois bem é sabido é que não há classe mais desprezada e miseravelmente tratada e que sofre castigos mais duros e caprichosos".

Os índios escravizados pelos colonos estrangeiros permanecem, desde os primeiros contatos, na camada mais baixa da população e representavam um produto valioso e disputado por eclesiásticos e portugueses até o século XVIII, quando foi abolida a escravidão indígena e incrementado o tráfico negreiro. A posse de índios era lucrativa a tal ponto que motivou uma disputa que engrossou os conflitos sociais e provocou a expulsão dos jesuítas em 1661 e 1684 (LIMA, 1981, p.74).

Em 1819, de acordo com os viajantes Spix e Martius (apud CALDEIRA, 2003, p.76), o número de índios aculturados era considerado baixo, somavam 9 mil, "extremamente pouco e só se explica pelas terríveis devastações, feitas pelas bexigas e outras doenças importadas pela Europa". Quanto aos isolados, estes eram mais de 80 mil. De acordo com os apontamentos desses autores, as nações existentes dividiam-se em timbiras, que habitavam entre os rios Balsas e Itapecuru; os gamelas, que viviam nas áreas dos rios Pindaré e Turiaçu 
e próximos às cidades de Viana e Monção; e Jês, moradores das margens dos rios Tocantins e Capim (apud CALDEIRA, 2003, p.77-80).

A população africana estava, ao lado dos índios, nos estamentos sociais mais segregados. O número de escravos cresceu a partir da segunda metade do século XVIII e se elevou gradativamente, embora se precisar quantos foram permanece um desafio para os pesquisadores dada a ausência de estatísticas concretas, porém Viveiros (1954, p.86-87) destaca as seguintes: 3 mil antes de 1755, 12 mil no período da Companhia de Comércio (1756-1777), 15 mil até o fim do século XVIII e 30 mil na centúria seguinte. O tratamento destinado aos escravos era desumano e cruel, de acordo com informações de Magalhães (2001, p. 20):

numerosos braços negros são tratados com tão bárbaro rigor, que até o necessário lhes negam: uma espiga de milho é o seu almoço, arroz e farinha o jantar, do mais lhes fornecem a rapina e a caça; andam nus ou cingidos com uma pequena tanga, salva as poucas exceções; e por isso procuraram os escravos subtrair-se ao jugo do senhorio. (MAGALHÃES, 2001, p. 20)

Os portugueses, descendentes e os estrange iros estavam no topo da pirâmide social. Eram latifundiários, lavradores, funcionários públicos e comerciantes. Não constituíam uma camada homogênea, seus elementos espalhavamse pela capital - lugar de autoridades consideradas despóticas e corruptas - e pelo interior, sede da aristocracia rural (LIMA, 1981, p.127). Esses segmentos sociais, ligados à camada de maior poder econômico, enfrentaram se no processo de independência brasileira em razão dos interesses econômicos e políticos em jogo, sintetizados na escolha entre a manutenção do pacto colonial ou o livre comércio.

Na confluência de diversas origens - portuguesas, indígenas e negras - a miscigenação é um dos traços da sociedade maranhense em formação entre os séculos XVIII e XIX, fator de tensões sociais, fomentadas pelos interesses políticos e a concentração de poder econômico. Aos índios, negros, cafuzos e mulatos, indivíduos das camadas mais baixas, a discriminação costumava ser tratamento corrente, como ilustra uma passagem de O Mulato, romance de Aluísio Azevedo sobre as diferenças sociais, ambientado em São Luís, no último quartel do século XIX. A mentalidade segregadora de elementos das classes mais ricas é percebida em uma das descrições da personagem Maria Bárbara, portuguesa de família abastada:

Maria Bárbara tinha o verdadeiro tipo das velhas maranhenses criadas na fazenda. Tratava muito os avós, quase todos portugueses; muito orgulhosa; muito cheia de escrúpulos de sangue. Quando falava nos pretos, dizia 'sujos' e, 
quando se referia a um mulato, dizia 'o cabra'. Sempre fora assim, e como devota, não havia outra. Em Alcântara tivera uma capela de Santa Bárbara e obrigava a sua escravatura a rezar aí todas as noites, em coro, de braços abertos, às vezes algemados. Lembrava-se com grandes suspiros do marido 'do seu João Hipólito', um português fino, de olhos azuis e cabelos loiros (AZEVEDO, 2003, p. 23)

Essa mesma elite, formada principalmente por brancos, ao vivenciar um segundo surto de crescimento econômico, registrado entre 1850 a 1870, como situa Lacroix (2002, p.71), erigiu novos hábitos - inspirados nas capitais européias. O luxo, a prosperidade e a sofisticação experimentados construíram a mentalidade de uma sociedade superior, afastada do legado lusitano. Nas décadas seguintes, com as dificuldades econômicas, agravadas com a abolição da escravatura, a perspectiva do sentimento aristocrático e da superioridade do homem da terra veia à tona e deu fôlego à origem francesa, decantadas por historiadores do século XX e negada pelos primeiros estudiosos da história maranhense.

A origem francesa é aplaudida e retificada por parte dos pesquisadores em fins do século do XIX, consolidando a data comemorativa da fundação da cidade, 08 de setembro, que marca a chegada dos franceses na região, apesar de não existirem edificações ou leis remanescentes do breve período da ocupação das tropas de La Ravardière, que permaneceram três anos no território maranhense, de 1612 a 1615 . Os casarões ainda hoje existentes foram conseqüência de obras da Coroa portuguesa, bem como as primeiras concepções referentes às habitações, as regras para uso da terra e o ordenamento do comércio.

Será que a vitória de Bequimão consistiu em plantar a semente da rejeição ao jugo português, a qual veio brotar quando a reação da qualquer idéia de dominação e subordinação foi fortalecida pelo ideário da França de 1789? Ou será que o mito da origem francesa, apoiado na idéia de singularidade, foi um mecanismo de auto-afirmação do maranhense na fase de declínio econômico e marasmo social? (LACROIX, 2002, p. 46)

Nesse panorama de pobreza, livros ou jornais não eram presença constante nos lares, comércios e igrejas, principalmente até o final do século XVIII. Pensamentos, idéias ou informações circulavam nas conversas ou nos panfletos manuscritos. A situação começou a alterar-se com a primeira tipografia maranhense, que chegou em São Luís em 1821, mantida pelo Erário Real, até 1830 foi a única a funcionar na província (SERRA, 2001, p.21). 


\section{Exclusão Social}

O desenvolvimento socioeconômico do território maranhense foi marcado por duas vertentes: a concentração de renda e de poder político. Como pontua Meireles (2001, p. 305), a província escravocrata e agrícola testemunhou o alargamento de suas bases, formadas por segmentos desprovidos de poder, escravos e homens livres, trabalhadores das propriedades privadas, e manteve intacta, no topo da pirâmide social, uma diminuta classe formada por portugueses e seus descendentes, detentora dos lucros e dos instrumentos políticos, que potencialmente podiam influenciar o destino do território.

Neste quadro, a exclusão social acentuourse, especialmente a partir do boom econômico do século XIX, com elevada produção de arroz e algodão para o exterior. Tomou corpo um abismo social, na qual as relações de classe caracterizavam se pela subordinação acentuada e pela predominância a ferro e fogo do pensamento da classe dominante sobre os segmentos mais baixos. Essas diferenças sociais contundentes desaguaram em conflitos sociais entre dominados e dominadores. Citemos os que entraram para a história maranhense: os conflitos entre colonos e jesuítas nos anos 1600 (LIMA, 1981, p. 70); a Revolta de Beckman, no mesmo século (LIBERMAN, 1983, p.83) e a Balaiada, entre 1831 e 1841 (PRADO JÚNIOR, 1993, p.78). Esses acontecimentos sintetizaram os choques travados entre grupos sociais distintos em razão de questões sociais, políticas e econômicas.

Um exemplo citado de conflito entre as classes sociais maranhenses personificourse na Balaiada, insurreição ocorrida nas regiões mais ricas da província, nas margens do Itapicuru e Parnaíba. Não se tratou de um único levante, agregou pequenos movimentos, abrangendo desde o litoral à ilha de São Luís. Seus personagens têm origens nas massas sertanejas e nos negros escravos. Os embates simbolizam a luta entre liberais e conservadores, classes médias contra grandes proprietários de terra, cidade versus interior (PRADO JÚNIOR, 1993, p.79). Na capital, os liberais eram conhecidos como bem-te-vis, em função do nome do jornal $O \mathrm{Bem}-\mathrm{Te}$-Vi, que reuniu os elementos democráticos. A insurreição não reuniu forças políticas consideráveis e apresentava-se com certa desarticulação. Os ânimos arrefeceram em 1841 com a chegada do coronel Luís Alves de Lima e Silva, duque de Caxias, e a reacomodação de forças políticas locais.

A desigualdade social na província do Maranhão, assinala Assunção (2000, p. 37), mostrava-se maior que nas demais províncias. Refere-se o autor ao fato de os comerciantes portugueses serem riquíssimos, possuírem muitas terras e acumularem um número elevado de escravos. Cita o exemplo do comerciante José Gonçalves da Silva, conhecido por "O Barateiro", 
dono de 1500 escravos e com fortuna calculada em 7 milhões de cruzados, e José Antonio Meireles, que concedia empréstimos na praça no valor de 1.200 contos.

Esse empresariado rural mercantil, formado por representantes do modelo econômico, grandes proprietários de terras e escravistas, pouco adequou sua produção agro-industrial, ao final do século XIX, às mudanças tecnológicas, preferindo aplicar os vultuosos recursos arrecadados em "padrão de vida suntuária" e "consumo ostentatório" (TRIBUZI, 1981, p.20). A concentração de renda e a falta de visão política demarcaram um quadro social caracterizado pela exclusão social, com a maioria da população à margem do processo decisório, e uma reduzida parcela usufruindo da riqueza gerada e ditando as regras do jogo político vigente.

A imprensa demorou a vingar nesse contexto sócio-político por conta do atraso econômico da província e da ausência de grupos sociais organizados, capazes de mobilizarem-se de forma sistemática em torno de causas coletivas e de proporem mudanças na estrutura política e no modelo econômico adotado, ou seja, grupos capazes de aquecer os jornais com a opinião e discutir propostas para os cenários que se formavam.

\subsection{Causa cultural}

\section{População analfabeta}

Um dos fatores que acanharam o desenvolvimento da imprensa foi o analfabetismo da população da província do Maranhão. O baixo número de escolas, restritas às camadas dominantes e a quase inexistente circulação de livros contribuíram para a vinda tardia dos impressos ao território.

Entre os primeiros habitantes da região, os índios, predominou a cultura oral por quase três séculos. Escravizados e domesticados pelos jesuítas, serviram como mão-de-obra até meados do século XVIII, quando o tráfico negreiro tomou corpo e gradativamente os escravos africanos foram obrigados a trabalhar na lavoura de algodão, produto mais lucrativo da região entre 1770 e 1820 (VIVEIROS, 1954, p.21). Chegando em maior número com a Companhia de Comércio do Grão-Pará e Maranhão no século XVIII, os negros, oriundos de culturas com tradição oral, foram marginalizados por uma sociedade estratificada e dominada por portugueses, que os tratava com preconceito e castigos dolorosos.

Esses povos, de "formação primitiva e cultura iletrada", compunham a maior parte da população maranhense. Em 1779, a maior parte da população do Maranhão era formada por 
78.860 mil habitantes, distribuídos da seguinte forma: negros (40,28\%), cafuzos $(23,53 \%)$ e $36,19 \%$ brancos, ou seja, $63,81 \%$ dos habitantes integravam as camadas mais pobres, em sua maior parte analfabeta (MEIRELES, 1994, p.303), ou seja, a maior parte da população não sabia ler nem escrever e estava empregada ou escravizada nas casas-grandes e fazendas.

No Maranhão, o analfabetismo preponderou até a segunda metade dos anos de 1800. Até então a capital possuía pouquíssimas escolas, onde mulheres não estudavam e o livro era um item raro. Lacroix (2002, p.62) comenta que em São Luís “com exceção do Lyceo e do Colégio Nossa Senhora da Glória, todos os outros estabelecimentos de ensino masculinos e femininos foram fundados na segunda metade do século XIX”. Há registros de um colégio com boa biblioteca fundado por jesuítas em 1627, chamado de Colégio Nossa Senhora da Luz, destinado aos filhos dos portugueses, porém foi fechado após a expulsão da Companhia de Jesus pelo Marques de Pombal (LIBERMAN, 193, p. 23).

Essa carência de escolas e de livros nos faz refletir sobre o impacto do analfabetismo na atividade jornalística. Para Cheche (2004, p. 3), o número de leitores de jornais era geralmente superior à tiragem dos impressos, ou seja, mais de uma pessoa, além do assinante, lia o jornal, sendo assim, as altas taxas de analfabetismo não seriam de fato tão limitadoras da expansão do jornalismo, uma atividade pouco popular no Maranhão no início do século XIX.

Para compreender de que forma os jornais influenciaram na trajetória do país ma primeira metade do século XIX, é necessário, sublinham Morel \& Barros (2003, p.45), compreender o cotidiano dos leitores e relativizar o rótulo de imprensa "elitista". À época, as tipografias e as livrarias transformaram-se em pontos de encontro; eram comuns as conversas entre redatores e leitores e a troca de informações. No entorno desses pontos de encontros, proliferavam jornais, cartazes e outros impressos. Foi comum também a leitura coletiva dos jornais, momento em que as culturas letradas e iletradas se encontravam, fomentando o nascimento de folhas, algumas efêmeras, e do aumento das tiragens.

Contudo, a movimentação em torno das tipografias e o número de leitores acima da tiragem dos periódicos não são fatores que amenizam o impacto das taxas eleva das de analfabetismo sobre o progresso do trabalho jornalístico e o interesse por livros. O analfabetismo não é um fenômeno que impede a implantação da imprensa, porém dificulta sua evolução, estanca a circulação e o debate de idéias, impede o crescimento do número de assinantes e escasseia a quantidade de anúncios oficiais ou publicitários, que costumam ser o sustentáculo dos jornais. 




\section{CAPÍTULO 02 \\ A DIFUSÃO DA IMPRENSA NO MARANHÃ̃ NOS SÉCULOS XIX E XX}

\section{Capítulo II}

\section{A DIFUSÃO DA IMPRENSA NO INTERIOR}

\section{A trilha dos primeiros jornais maranhenses}

O desenvolvimento da imprensa no Maranhão começou em São Luís, localizada no extremo morte, em 1821, concentradora até então das principais atividades comerciais da região, chegando a ter o quarto porto exportador do Brasil (ASSUNÇÃO, 2000, p. 37). No rastro do breve progresso econômico, capitaneado pela Companhia do Grão-Pará e Maranhão e da exportação de produtos agrícolas, no final do século XVIII, a cidade foi superando 
paulatinamente as carências socioculturais remanescentes. Foram estancadas as causas que dificultaram a chegada da imprensa nas regiões Norte e Nordeste do território português no continente americano e aplainado o terreno que possibilitou o surgimento do jornal pioneiro e a expansão do jornalismo na capital.

Iniciada no Norte do território, a implantação da letra impressa percorreu em seguida o Leste, a região Central, chegando ao Sul e por fim ao Oeste, região que somente obteve crescimento econômico acentuado em meados do século XX. No interior, a marcha dos jornais seguiu lenta, pois as motivações sociais, culturais, políticas e econômicas sustentadoras da vinda tardia dos impressos continuaram a predominar na maioria das cidades.

A interiorização da imprensa seguiu os mesmos passos do crescimento socioeconômico, centrado na capital e calcado no modelo essencialmente exportador até as primeiras décadas dos anos 1800, quando foi abalado pelas mudanças do mercado externo. O Estado maranhense enfrentou então três tipos de crises que ameaçavam o breve progresso econômico do território ao longo do século XIX, momento histórico do surgimento dos primeiros jornais (ASSUNÇÃO, 2000 , p. 53). A primeira crise foi ocasionada pela queda do preço do algodão, resultado da estrutura de produção e comercialização; a segunda, gerada pelas chamadas causas naturais, a exemplo da seca, causando a falta de farinha e outros produtos básicos. A terceira crise assentava-se no abastecimento, atingindo principalmente parte da população que não tinha condições de produzir para o próprio sustento.

Essas crises de subsistência, como afirma o autor, têm fundamento na estrutura fundiária, que isolou os pequenos agricultores, alojando-os nas áreas mais desfavoráveis ao plantio, na ação de atravessadores e na falta de estradas e transportes. À sombra dessas dificuldades, a economia "caboclizou-se", ampliando-se a produção de subsistência, ao contrário do que ocorreu em Minas Gerais ou São Paulo, onde o mercado interno cresceu no século XIX, abrindo as portas ao processo de industrialização (ASSUNÇÃO, 2000, p. 56).

Enquanto o interior expandia-se a passos lentos em função do modelo econômico adotado, São Luís e as cidades do seu entorno, localizadas nas áreas de maior ocupação, esboçavam um processo de modernização na segunda metade do século XIX, sustentado pela instalação de fábricas têxteis: das 13 estudadas por Ribeiro Júnior (2001, p. 71), 8 foram implantadas em São Luís e 5 no interior, precisamente 4 nos municípios de Caxias e Codó, que estão entre as primeiras cinco localidades a efetivar a implantação da imprensa no Estado. $\mathrm{Na}$ capital, o parque industrial incorporou 1.550 empregados e no interior 960, representando o ímpeto de transformar um "estado agrícola" em "estado industrial" sem o governo local 
operacionalizar as condições necessárias, o que impediu um progresso permanente e gradual a todo o território. Esses bafejos de modernização colaboraram para a proliferação dos impressos, porém o atraso persistente, por outro lado, diminuiu a marcha da imprensa.

As primeiras tentativas de mapear o surgimento da imprensa maranhense, compreendendo, além de São Luís, as cidades das demais regiões do território, remontam a 1883, quando o jornalista, professor fundador e diretor de jornais, Joaquim Serra, escreveu Sessenta Anos de Jornalismo - A Imprensa no Maranhão, o qual lista o nascimento de jornais, porém sem remetê-los à cidade de origem, o que nos faz deduzir que compilou somente impressos de São Luís. Marques (1878), no mesmo século, publicou um estudo sobre a imprensa no Maranhão, na revista do Instituto Histórico e Geográfico Brasileiro, com informações sobre a imprensa da Província e referências a jornais de São Luís, Viana, Caxias e aos jornais religiosos.

Em 1959, Lopes (1959) analisou a imprensa estadual, incluindo periódicos do interior, das cidades de Caxias, Codó, Barra do Corda, Viana e Grajaú. Em sua obra há um capítulo pormenorizado e crítico de fontes sobre o jornalismo maranhense, análise rara encontrada em referências bibliográfica sobre o tema. Nesta publicação as informações coletadas referem se somente ao período de circulação e aos seus fundadores, com descrição da vida de jornalistas que marcaram a história da imprensa local.

Lopes (1959, p.15-18) afirma que na ordem cronológica a primeira publicação sobre a imprensa local foi de autoria de Francisco Sotero dos Reis em artigos para o jornal Publicador Maranhense, que circulou entre 1842 e 1886, contudo, não há coleção completa do referido impresso, prejudicando os trabalhos de pesquisa. Outras fontes, segundo o autor, são os artigos do advogado, jornalista e político João da Mata Moraes Rego no jornal Pacotilha, cuja circulação com interrupções ocorreu entre 1880 a 1938, mas nimos a-los não foi possível, esclareceu Antônio Lopes, porque a coleção completa do referido periódico pertencia, à época da sua investigação, a arquivos particulares que não estavam abertos ao público. Um documento destacado, embora com falhas e imprecisões, é o catálogo elaborado pelo jurisconsulto maranhense Augusto Olímpio Viveiros, que chegou a ser ministro do Superior Tribunal Federal do país, publicado em Revista do Instituto Histórico e Geográfico Brasileiro no primeiro Centenário da Imprensa Periódica Brasileira (LOPES, 1959, p.17).

No século XX, depois da análise de Antônio Lopes, encontramos as pesquisas publicadas por Jorge (1987), em Os Primeiros Passos da Imprensa no Maranhão, em que o autor estudou 62 jornais, embora todos fundados na capital. É também de sua autoria os livros Jornalismo Movido a Paixão (2000) e A Linguagem dos Pasquins (1998), nos quais investiga momentos da imprensa 
do Maranhão: os embates políticos entre os jornais O Censor e Argos da Lei e a proliferação de pasquins nas ruas de São Luís em meados do século XIX, espaços de ataques pessoais, desavenças e xingamentos, surgidos no rastro das mudanças políticas e sociais no território após a independência brasileira.

A publicação mais recente com informações de jornais de todo o Estado foi organizada por Nascimento (2007), ainda inédita, com uma a edição atualizada dos jornais do acervo da Biblioteca Benedito Leite, compreendendo o período entre 1821 a 2006, que representa o maior e mais importante arquivo de impressos no Maranhão. A primeira versão do catálogo, com jornais e revistas registrados entre 1821 a 1979, foi publicada inicialmente por Silva (1981). Na primeira versão, havia 446 títulos e na segunda edição o número é de 510 títulos.

Ressaltamos que o catálogo é uma referência relevante sobre o avanço dos impressos em todo o Maranhão. Porém, não podemos afirmar que todos os jornais que circularam no Maranhão estejam arquivados na Biblioteca Benedito Leite, mesmo assim o acervo é precioso e nos dará pistas sobre o desenvolvimento da imprensa maranhense, além de permitir delinear um perfil inicial dos jornais que circularam no Estado.

Em nosso estudo, nos embasaremos principalmente em obras sobre a imprensa do Maranhão de Lopes (1959), Silva (1981), Jorge (1987), Serra (2001) e Frias (2001). No tocante às referências sobre as vocações econômicas, aspectos geográficos, perfis demográficos e indicadores sociais, nos apoiaremos nas reflexões de Coelho Netto (1979), Paxeco (1998), Coutinho (1994), Meirelles (2001), Nascimento (2001), Cabral (1992) e Viveiros (1954).

Conforme Nascimento (2007), foram necessários 185 anos para a atividade impressa atingir 15\% do quadro de 217 municípios no Estado. Dessa forma, ao final do século XX, 182 municípios continuavam sem registros de jornais. É notável que do total de 33 cidades, 16 estejam situadas na região Norte, 9 na região Leste, 4 no Centro, 3 no Sul e 2 no Oeste do Estado. Do total de 33 municípios, apenas 6 lançaram seus periódicos no século XIX, os demais 27 somente os tiveram na centúria seguinte (SILVA, 1981). A seguir, quadro das cidades, seus respectivos jornais e a data de fundação de cada um.

\section{QUADRO 5}

Municípios maranhenses e seus jornais pioneiros entre 1821-2006

\begin{tabular}{|l|l|l|l|}
\hline \multicolumn{1}{|c|}{ Município } & \multicolumn{1}{c|}{ Título } & \multicolumn{1}{c|}{ Ano } & \multicolumn{1}{c|}{ Região } \\
\hline São Luís & O Conciliador do Maranhão & 1821 & Norte \\
\hline Caxias & O Telégrafo* $^{*}$ & 1848 & Leste \\
\hline
\end{tabular}




\begin{tabular}{|c|c|c|c|}
\hline Viana & Alavanca & 1876 & Norte \\
\hline Codó & Gazeta de Codó & $1892^{* * *}$ & Leste \\
\hline Barra do Corda & O Norte & $1892 * * *$ & Centro \\
\hline Picos & O Município & 1895 & Leste \\
\hline Rosário & O Rosariense & 1903 & Norte \\
\hline Loreto & O Ideal & 1904 & Sul \\
\hline Alcântara & Alcantariense & 1906 & Norte \\
\hline Flores & O Trabalho & 1906 & \begin{tabular}{|l} 
Leste \\
\end{tabular} \\
\hline Brejo & Anapurus & 1907 & Leste \\
\hline Carolina & O Tocantins & 1914 & Sul \\
\hline Buriti Bravo & O Sertanejo & 1917 & Leste \\
\hline Mirador & O Dia & 1917 & Leste \\
\hline Cururupu & O Litoral & 1917 & Norte \\
\hline Grajaú & O Telescópio+ & 1917 & Centro \\
\hline Coroatá & O Coroatá & 1919 & \begin{tabular}{|l} 
Leste \\
\end{tabular} \\
\hline Pedreiras & A Ordem & 1920 & Centro \\
\hline Pinheiro & Cidade de Pinheiro & 1921 & Norte \\
\hline $\begin{array}{l}\text { São Vicente } \\
\text { Ferrer }\end{array}$ & O Cruzeiro & 1928 & Norte \\
\hline Morros & A Luz & 1931 & Norte \\
\hline Imperatriz & O Alicate++ & 1932 & Oeste \\
\hline $\begin{array}{l}\text { Humberto de } \\
\text { Campos } \\
\text { São Bento }\end{array}$ & $\begin{array}{l}\text { Poeira } \\
\text { Legionário }\end{array}$ & $\begin{array}{l}1935 \\
1935\end{array}$ & $\begin{array}{l}\text { Norte } \\
\text { Norte }\end{array}$ \\
\hline Itapecuru-Mirim & Trabalhista & 1946 & Norte \\
\hline Arari & Boletim Paroquial & 1953 & Norte \\
\hline
\end{tabular}




\begin{tabular}{|l|l|l|l|} 
& $\begin{array}{l}\text { Voz da União Recreativa } \\
\text { Estudantil Bacabalense }\end{array}$ & 1954 & Centro \\
\hline Timon & Correio de Timon & 1956 & Leste \\
\hline Miranda do Norte & O Mearim & 1990 & Norte \\
\hline Chapadinha & Gazeta Popular & 1993 & Leste \\
\hline São Mateus & Folha de São Mateus & 1997 & Leste \\
\hline $\begin{array}{l}\text { Paço do Lumiar } \\
\text { Vitória do Mearim }\end{array}$ & O Correio do Maiobão & 1998 & Norte
\end{tabular}

